Eur J Clin Chem Clin Biochem

1995; 33:31-52

(c) 1995 Walter de Gruyter \& Co.

Berlin - New York

\title{
The Influence of Bilirubin, Haemolysis and Turbidity on 20 Analytical Tests Performed on Automatic Analysers
}

Results of an interlaboratory study

\author{
By D. Grafmeyer ${ }^{1}$, M. Bondon', M. Manchon ${ }^{2}$ and P. Levillain ${ }^{3}$ \\ ${ }^{1}$ Hôpital de la Croix-Rousse, Laboratoire de Biochimie, Lyon, France \\ 2 Centre Hospitalier Lyon-Sud, Laboratoire de Biochimie, Pierre-Bénite, France \\ 3 Hôpital Fernand Widal, Laboratoire de Toxicologie, Paris, France
}

(Received June 2/September 15, 1994)

Summary: The director of a laboratory has to be sure to give out reliable results for routine tests on automatic analysers regardless of the clinical context. However, he may find hyperbilirubinaemia in some circumstances, parenteral nutrition causing turbidity in others, and haemolysis occurring if sampling is difficult. For this reason, the Commission for Instrumentation of the Société Française de Biologie Clinique (SFBC) (president Alain Feuillu) decided to look into "visible" interferences - bilirubin, haemolysis and turbidity - and their effect on 20 major tests: 13 substrates/chemistries: albumin, calcium, cholesterol, creatinine, glucose, iron, magnesium, phosphorus, total bilirubin, total proteins, triacylglycerols, uric acid, urea, and 7 enzymatic activities: alkaline phosphatase, alanine aminotransferase, $\alpha$-amylase, aspartate aminotransferase, creatine kinase, $\gamma$-glutamyl transferase and lactate dehydrogenase measured on 15 automatic analysers representative of those found on the French market (Astra 8, AU 510, AU 5010, AU 5000, Chem 1, CX 7, Dax 72, Dimension, Ektachem, Hitachi 717, Hitachi 737, Hitachi 747, Monarch, Open 30, Paramax, Wako $30 \mathrm{R}$ ) and to see how much they affect the accuracy of results under routine conditions in the laboratory.

The study was carried out following the SFBC protocol for the validation of techniques using spiked plasma pools with bilirubin, ditauro-bilirubin, haemoglobin (from haemolysate) and Intralipid ${ }^{\mathrm{TM}}$ (turbidity).

Overall, the following results were obtained: haemolysis affects tests the most often (34.5\% of cases); total bilirubin interferes in $21.7 \%$ of cases; direct bilirubin and turbidity seem to interfere less at around $17 \%$. The different tests are not affected to the same extent; enzyme activity is hardly affected at all; on the other hand certain major tests are extremely sensitive, increasingly so as we go through the following: creatinine (interference of bilirubin), triacylglycerols (interference of bilirubin and haemoglobin), glucose (interference of bilirubin), cholesterol (interference of bilirubin), phosphorus (interference of bilirubin and haemoglobin), uric acid (interference of turbidity), iron (interference of haemoglobin and turbidity), total proteins (interference of bilirubin, haemoglobin and turbidity) and bilirubin (interference of haemoglobin and turbidity). Three categories of interferences can be found: interference by addition, chemical interference and spectral interference, and the results show that not only the choice of a method is important on the analyser, but also how this has been adapted.

By looking into these conditions carefully, it is sometimes possible to find a reason for the problem and thereby a simple solution to correct it. If the different factors are defined with care in terms of the reaction, use of a sample blank or not, choice of secondary wavelength etc., the influence of the interferences can be better kept under 
control. During the study we have particularly noted how poorly effective bichromatic procedures are; the choice of the secondary wavelength did not always prove useful, and thus the "corrections" were often not effective or only slightly so, or even had the contrary effect.

\section{Introduction}

In 1991, the committee for instrumentation of the Société Française de Biologie Clinique (SFBC), president Alain Feuillu, decided to study the influence of "visible"

\footnotetext{
1) Enzymes

$\alpha$-Amylase:

$\alpha$-1,4-glucan 4-glucanhydrolase (EC 3.2.1.1)

Alanine amino transferase:

$L$-alanine : 2-oxoglutarate aminotransferase (EC 2.6.1.2)

Alkaline phosphatase:

orthophosphoric monoester phosphohydrolase (alkaline optimum) (EC 3.13.1)

Aspartate amino transferase:

$L$-aspartate : 2-oxoglutarate aminotransferase (EC 2.6.1.1)

Creatine kinase:

ATP : creatine $\mathrm{N}$ phosphotransferase (EC 2.7.3.2)

$\gamma$-Glutamyl transferase:

$\gamma$-glutamyl transpeptidase (EC 2.3.2.2)

Lactate dehydrogenase:

$L$-lactate $: \mathrm{NAD}^{+}$oxidoreductase (EC 1.1.1.27)
}

interferences - bilirubin, haemolyșiș, turbidity - on the major routine tests carried out on automatic analysers. In many laboratories today, directors are often unaware of this type of problem. This led the committee to study how much these interferences affect the accuracy of results obtained for 20 routine analytes.

The results were presented at a workshop held in Eurolab (Nice - France) on the 29 April 1993.

\section{Materials and Methods}

\subsection{Instruments and analytes}

The instruments included in the study consisted of a sample representative of those found on the French market. The list was compiled with the aid of manufacturers and distributors as well as in collaboration with colleagues in the profession. We tried to have 2 sites for each instrument when possible. Table 1 lists the instruments evaluated with the corresponding sites.

Tab. 1 Instruments tested and evaluation sites.

\begin{tabular}{|c|c|c|c|c|}
\hline Manufacturer & Instrument & & Evaluation site & Person in charge \\
\hline Beckman & Astra & $\begin{array}{l}(1) \\
(2)\end{array}$ & $\begin{array}{l}\text { CHLS - Secteur Ste Eugénie - Lyon } \\
\text { CHLS - Secteur J. Courmont - Lyon }\end{array}$ & $\begin{array}{l}\text { R. C. Boisson } \\
\text { M. Manchon }\end{array}$ \\
\hline \multirow[t]{2}{*}{ Merck } & AU 510 & $\begin{array}{l}(1) \\
(2)\end{array}$ & $\begin{array}{l}\mathrm{CH} \text { de Martigues } \\
\mathrm{CH} \text { de Thonon }\end{array}$ & $\begin{array}{l}\text { P. Desvignes } \\
\text { F. Joncquiert }\end{array}$ \\
\hline & $\begin{array}{l}\text { AU } 5010 \\
\text { AU } 5000\end{array}$ & $\begin{array}{l}(1) \\
(2)\end{array}$ & $\begin{array}{l}\text { Centre de Méd. Prév. Nancy } \\
\text { CHLS - Secteur J. Courmont - Lyon }\end{array}$ & $\begin{array}{l}\text { F. Schiele-J. Henny } \\
\text { M. C. Carlier-P. Baltassat }\end{array}$ \\
\hline Bayer & Chem I & $\begin{array}{l}(1) \\
(2)\end{array}$ & $\begin{array}{l}\text { HIA Desgenettes - Lyon } \\
\mathrm{CH} \text { de Thionville }\end{array}$ & $\begin{array}{l}\text { Y. Robet } \\
\text { B. Capolaghi }\end{array}$ \\
\hline Beckman & $\mathrm{CX} 7$ & $\begin{array}{l}(1) \\
(2)\end{array}$ & $\begin{array}{l}\text { CHLS - Secteur J. Courmont - Lyon } \\
\mathrm{CH} \text { de Meaux }\end{array}$ & $\begin{array}{l}\text { M. Manchon } \\
Y \text {. Gourmelin }\end{array}$ \\
\hline Bayer & Dax 72 & (1) & GH Sud du CHR de Bordeaux & R. Crockett \\
\hline Dupont & Dimension & $\begin{array}{l}(1) \\
(2)\end{array}$ & $\begin{array}{l}\text { Hôp. F. WIDAL - Paris } \\
\text { CH de Nemours }\end{array}$ & $\begin{array}{l}\text { C. Caliez-P. Levillain } \\
\text { J. Morice-M. Porcheron }\end{array}$ \\
\hline Kodak & Ektachem & $\begin{array}{l}(1) \\
(2)\end{array}$ & $\begin{array}{l}\text { CHU de Rangueil - Toulouse } \\
\text { HIA Begin - Saint Mandé }\end{array}$ & $\begin{array}{l}\text { M. Lagente-P. Valdiguié } \\
\text { J. P. Yvert }\end{array}$ \\
\hline \multirow[t]{3}{*}{ Boehringer } & Hitachi 717 & $\begin{array}{l}(1) \\
(2) \\
(3)\end{array}$ & $\begin{array}{l}\text { CHU Pontchaillou - Rennes } \\
\text { CH de Thionville } \\
\text { Soc. Boehringer - Meylan }\end{array}$ & $\begin{array}{l}\text { A. Feuillu. } \\
\text { B. Capolaghi } \\
\text { M. C. Lotz-C. Metier }\end{array}$ \\
\hline & Hitachi 737 & (1) & HIA Begin - Saint Mandé & $J . P$. Yvert \\
\hline & Hitachi 747 & (1) & $\mathrm{CH}$ de Mulhouse & M. Dorr-C. Merzullo-M. O. Michotey \\
\hline $\begin{array}{l}\text { Instrumentation } \\
\text { Laboratory }\end{array}$ & Monarch & $\begin{array}{l}(1) \\
(2)\end{array}$ & $\begin{array}{l}\text { Hôp. Ste Marguerite - Marseille } \\
\text { CH de Limeil Brevannes }\end{array}$ & $\begin{array}{l}\text { A. M. Pauli } \\
\text { S. Troupel-C. Laureaux }\end{array}$ \\
\hline Biomérieux & Open 30 & $\begin{array}{l}(1) \\
(2)\end{array}$ & $\begin{array}{l}\text { Hôp. Croix-Rousse - Lyon } \\
\text { CHLS - Secteur Ste Eugénie - Lyon }\end{array}$ & $\begin{array}{l}\text { M. Bondon-D. Grafmeyer } \\
\text { R. C. Boisson }\end{array}$ \\
\hline Baxter & Paramax & $\begin{array}{l}(1) \\
(2)\end{array}$ & $\begin{array}{l}\mathrm{CH} \text { de Douai } \\
\text { GH sud du CHR de Bordeaux }\end{array}$ & $\begin{array}{l}P . \text { Fievet-J. J. Kapoun } \\
\text { R. Crockett }\end{array}$ \\
\hline Serono & Wako $30 \mathrm{R}$ & (1) & HIA Desgenettes - Lyon & Y. Robet \\
\hline
\end{tabular}


The following analytes were studied: 13 substrates/chemistries, albumin, calcium, cholesterol, creatinine, glucose, iron, magnesium, phosphorus, total bilirubin, total proteins, triacylglycerols, uric acid and urea; and 7 enzymatic activities: alkaline phosphatase, alanine aminotransferase, $\alpha$-amylase, aspartate aminotransferase, creatine kinase, $\gamma$-glutamyl transferase and lactate dehydrogenase.

Of course, for closed systems, Astra, Chem 1, one part of the CX 7 , Dimension, Ektachem, Paramax, the methods used are those provided by the manufacturers; for open systems, the methods used are described in table 2 for chemistries and table 3 for enzyme activities measurements.

\subsection{Materials}

Bilirubin was obtained from Fluka (Mulhouse, France); conjugated bilirubin (sodium salt of ditauro-bilirubin) from Porphyrin Products (Paris, France); Intralipid ${ }^{\mathrm{TM}}$ (a 20\% fat emulsion for intravenous injection) from Kabi Pharmacia (Paris, France).

\subsection{Plasma pools}

Plasma pools were made up as carefully as possible to ensure the best results, i.e. trying to have concentrations of the analytes that iwill easily show the apparent increases or decreases due to the various additions made (tab. 4). Also, we asked the evaluators to avoid using pools that already show haemolytic, icteric or lipaemic aspects. This implied preparing as many as 7 different pools.

\subsection{Preparation of spiked solutions}

Starting from freshly prepared stock solutions of bilirubin 5.1 $\mathrm{mmol} / 1$ in $0.025 \mathrm{mmol} / \mathrm{l} \mathrm{NaOH}$, ditauro-bilirubin $5.1 \mathrm{mmol} / \mathrm{l}$ in distilled water, plasma pools were prepared containing bilirubin concentrations between 0 and $500 \mu \mathrm{mol} / 1$, and ditauro-bilirubin concentrations between 0 and $250 \mu \mathrm{mol} / \mathrm{l}$. These pools were analysed immediately. Using a solution of haemolysed erythrocytes in distilled water, plasma pools were prepared containing haemoglobin concentrations between 0 and $240 \mu \mathrm{mol} / \mathrm{l}$; the concentration of haemoglobin was tested for all samples. Intralipid was added to plasma pools in order to obtain turbidity, tested by measuring the absorbance at $600 \mathrm{~nm}$ of a $1: 20$ dilution in $150 \mathrm{mmol} / \mathrm{l} \mathrm{NaCl}$ of the spiked plasma pools (turbidity index), equivalent to those of fresh sera with a concentration of triacylglycerols up to $7 \mathrm{mmol} / \mathrm{l}$.

\subsection{Protocol, procedure}

The study was carried out using the SFBC protocol for the validation of techniques ("VALTEC") (1), in particular, appendix 9. The

Tab. 2 Methods used for chemistries determinations on open systems.

\begin{tabular}{|c|c|c|c|}
\hline Analyte & Method group & Instrument & Reagent source \\
\hline Albumin & Bromocresol green & $\begin{array}{l}\text { CX } 7(2) \\
\text { Hitachi } 717(1) \\
\text { Monarch (1) } \\
\text { Wako } 30 \mathrm{R}\end{array}$ & $\begin{array}{l}\text { Biomerieux } \\
\text { Boehringer } \\
\text { Instrumentation Lab. } \\
\text { Serono }\end{array}$ \\
\hline \multirow[t]{2}{*}{ Calcium } & o-Cresolphthalein complexone & $\begin{array}{l}\text { AU } 510 \text { - AU } 5010(1)-\text { AU } 5000(2) \\
\text { Dax } 72 \\
\text { Hitachi } 717(1),(2),(3)-\text { Hitachi } 747 \\
\text { Monarch (1), (2) } \\
\text { Wako } 30 \mathrm{R}\end{array}$ & $\begin{array}{l}\text { Merck } \\
\text { Bayer } \\
\text { Boehringer } \\
\text { Instrumentation Lab. } \\
\text { Serono }\end{array}$ \\
\hline & Arsenazo III & Hitachi 737 & Kone \\
\hline Cholesterol & Cholesterol oxidase/peroxidase & $\begin{array}{l}\text { AU } 510(1),(2)-\text { AU } 5010(1) \\
\text { CX } 7(2) \\
\text { Dax } 72 \\
\text { Hitachi } 717(2)-\text { Hitachi } 737 \text { - Hitachi } 747 \\
\text { Monarch (1), (2) } \\
\text { Open } 30(1),(2) \\
\text { Wako } 30 \mathrm{R}\end{array}$ & $\begin{array}{l}\text { Merck } \\
\text { Biomerieux } \\
\text { Bayer } \\
\text { Boehringer } \\
\text { Instrumentation Lab. } \\
\text { Biomerieux } \\
\text { Serono }\end{array}$ \\
\hline \multirow[t]{2}{*}{ Creatinine } & Jaffé kinetic & $\begin{array}{l}\text { AU } 510(1)-\text { AU } 5000(2) \\
\text { Dax } 72 \\
\text { Hitachi } 717 \text { (2), (3) - Hitachi } 737 \text { - Hitachi } 747 \\
\text { Monarch (1), (2) } \\
\text { Wako } 30 \mathrm{R}\end{array}$ & $\begin{array}{l}\text { Merck } \\
\text { Bayer } \\
\text { Boehringer } \\
\text { Instrumentation Lab. } \\
\text { Serono }\end{array}$ \\
\hline & Enzymatic & Hitachi $717(1)$ & Boehringer \\
\hline Glucose & Glucose oxidase/peroxidase & $\begin{array}{l}\text { AU } 510(2)-\text { AU } 5000(2) \\
\text { Dax } 72 \\
\text { Hitachi } 717 \text { (1), (2) - Hitachi } 737 \text { - Hitachi } 747 \\
\text { Monarch (1), (2) } \\
\text { Wako } 30 \mathrm{R}\end{array}$ & $\begin{array}{l}\text { Merck } \\
\text { Bayer } \\
\text { Boehringer } \\
\text { Instrumentation Lab. } \\
\text { Serono }\end{array}$ \\
\hline \multirow[t]{2}{*}{ Iron } & Ferene & $\begin{array}{l}\text { Hitachi } 717 \text { (2) - Hitachi } 737 \\
\text { Monarch (1) }\end{array}$ & $\begin{array}{l}\text { Kone } \\
\text { Instrumentation Lab. }\end{array}$ \\
\hline & Ferrozine & $\begin{array}{l}\text { AU } 510(1),(2) \\
\text { CX } 7(2) \\
\text { Hitachi } 717(3) \\
\text { Hitachi } 747 \\
\text { Open } 30(2) \\
\text { Wako } 30 \mathrm{R}\end{array}$ & $\begin{array}{l}\text { Merck } \\
\text { Biomerieux } \\
\text { Boehringer } \\
\text { Merck } \\
\text { Biomerieux } \\
\text { Serono }\end{array}$ \\
\hline
\end{tabular}


Tab. 2 (continued)

\begin{tabular}{|c|c|c|c|}
\hline Analyte & Method group & Instrument & Reagent source \\
\hline \multirow[t]{2}{*}{ Magnesium } & Calmagite & $\begin{array}{l}\text { CX } 7(1) \\
\text { CX } 7(2) \\
\text { Hitachi } 747\end{array}$ & $\begin{array}{l}\text { Beckman } \\
\text { Biomerieux } \\
\text { Biomerieux }\end{array}$ \\
\hline & Magon & $\begin{array}{l}\text { AU } 510(1),(2)-A U 5000(2) \\
\text { Wako } 30 \mathrm{R}\end{array}$ & $\begin{array}{l}\text { Merck } \\
\text { Serono }\end{array}$ \\
\hline Phosphorus & Phosphomolybdate & $\begin{array}{l}\text { AU } 510(1)-\text { AU } 5010(1)-\text { AU } 5000(2) \\
\text { AU } 510(2) \\
\text { CX } 7(1),(2) \\
\text { Dax } 72 \\
\text { Hitachi } 717(1) \\
\text { Hitachi } 717(2) \text { - Hitachi } 737 \text { - Hitachi } 747 \\
\text { Monarch (1) } \\
\text { Open } 30(1),(2) \\
\text { Wako } 30 \mathrm{R}\end{array}$ & $\begin{array}{l}\text { Merck } \\
\text { Biomerieux } \\
\text { Biomerieux } \\
\text { Bayer } \\
\text { Biomerieux } \\
\text { Boehringer } \\
\text { Instrumentation Lab. } \\
\text { Biomerieux } \\
\text { Serono }\end{array}$ \\
\hline \multirow[t]{2}{*}{ Proteins } & Biuret with iodide & $\begin{array}{l}\text { AU } 510(1)-\text { AU } 5010(1) \\
\text { Hitachi } 717(1),(2)-\text { Hitachi } 737-\text { Hitachi } 747 \\
\text { Monarch (1), (2) } \\
\text { Wako } 30 \mathrm{R}\end{array}$ & $\begin{array}{l}\text { Merck } \\
\text { Boehringer } \\
\text { Instrumentation Lab. } \\
\text { Serono }\end{array}$ \\
\hline & Biuret without iodide & $\begin{array}{l}\operatorname{CX} 7(1),(2) \\
\operatorname{Dax} 72\end{array}$ & $\begin{array}{l}\text { Beckman } \\
\text { Bayer }\end{array}$ \\
\hline \multirow[t]{4}{*}{ Total bilirubin } & $\begin{array}{l}\text { Jendrassik (benzoate caffeine) } \\
\text { - neutral pH } \\
\text { - alkaline pH }\end{array}$ & $\begin{array}{l}\text { AU } 5000(2) \\
\text { CX } 7(1),(2) \\
\text { Hitachi } 717(2),(3)-\text { Hitachi } 737\end{array}$ & $\begin{array}{l}\text { Merck } \\
\text { Beckman } \\
\text { Boehringer }\end{array}$ \\
\hline & Jendrassik (DMSO), neutral pH & Open $30(1),(2)$ & Biomerieux \\
\hline & Diphenyl diazonium (DPD) & $\begin{array}{l}\text { AU } 510(1),(2)-\text { AU } 5010(1) \\
\text { Hitachi } 717(1)-\text { Hitachi } 747\end{array}$ & $\begin{array}{l}\text { Merck } \\
\text { Boehringer }\end{array}$ \\
\hline & Others diazo reagents & $\begin{array}{l}\text { Dax } 72 \\
\text { Monarch (1), (2) } \\
\text { Wako } 30 \mathrm{R}\end{array}$ & $\begin{array}{l}\text { Bayer } \\
\text { Instrumentation Lab. } \\
\text { Serono }\end{array}$ \\
\hline \multirow[t]{2}{*}{ Triacylglycerols } & Enzymatic 340 nm & Open $30(1)$ & Biotrol \\
\hline & Enzymatic Trinder & $\begin{array}{l}\text { AU } 510(1),(2)-\text { AU } 5010(1) \\
\text { CX } 7(2) \\
\text { Dax } 72 \\
\text { Hitachi } 717(2)-\text { Hitachi } 737 \text { - Hitachi } 747 \\
\text { Monarch (1), (2) } \\
\text { Open } 30(2) \\
\text { Wako } 30 \mathrm{R}\end{array}$ & $\begin{array}{l}\text { Merck } \\
\text { Biomerieux } \\
\text { Bayer } \\
\text { Boehringer } \\
\text { Instrumentation Lab. } \\
\text { Biomerieux } \\
\text { Serono }\end{array}$ \\
\hline Urea & Urease/glutamate dehydrogenase & $\begin{array}{l}\text { AU } 510(1)-\text { AU } 5000(2) \\
\text { Dax } 72 \\
\text { Hitachi } 717(1)-\text { Hitachi } 737-\text { Hitachi } 747 \\
\text { Hitachi } 717(2) \\
\text { Monarch (1) } \\
\text { Wako } 30 \text { R }\end{array}$ & $\begin{array}{l}\text { Merck } \\
\text { Bayer } \\
\text { Boehringer } \\
\text { Biomerieux } \\
\text { Instrumentation Lab. } \\
\text { Serono }\end{array}$ \\
\hline \multirow[t]{2}{*}{ Uric acid } & Uricase/catalase/dehydrogenase & $\begin{array}{l}\text { AU } 510(2) \\
\text { AU } 5000(2) \\
\text { CX } 7(1) \\
\text { CX } 7(2) \\
\text { Open } 30(1),(2)\end{array}$ & $\begin{array}{l}\text { Biomerieux } \\
\text { Merck } \\
\text { Biotrol } \\
\text { Biomerieux } \\
\text { Biotrol }\end{array}$ \\
\hline & Uricase/peroxidase & $\begin{array}{l}\text { AU } 510(1)-\text { AU } 5010(1) \\
\text { Dax } 72 \\
\text { Hitachi } 717(1),(2)-\text { Hitachi } 737-\text { Hitachi } 747 \\
\text { Monarch (1), (2) } \\
\text { Wako } 30 \mathrm{R}\end{array}$ & $\begin{array}{l}\text { Merck } \\
\text { Bayer } \\
\text { Boehringer } \\
\text { Instrumentation Lab. } \\
\text { Serono }\end{array}$ \\
\hline
\end{tabular}


Tab. 3 Methods used for enzymatic activities measurement on open/systems.

All systems work at $37^{\circ} \mathrm{C}$ except CX 7 (2), Hitachi 717 (3), Hitachi 737, Monarch (1) and (2) which work at $30^{\circ} \mathrm{C}$.

\begin{tabular}{|c|c|c|c|}
\hline Analyte & Method group & Instrument & Reagent source \\
\hline \multirow[t]{3}{*}{$\begin{array}{l}\text { Alanine amino- } \\
\text { transferase } \\
\text { and aspartate } \\
\text { amino- } \\
\text { transferase }\end{array}$} & $\begin{array}{l}\text { Acc. to SFBC/IFCC } \\
\text { (with pyridoxal-5-phosphate) }\end{array}$ & $\begin{array}{l}\text { AU } 510(2) \\
\text { AU } 5000(2) \\
\text { CX } 7(1),(2) \\
\text { Hitachi } 717(2) \\
\text { Open } 30(1),(2)\end{array}$ & $\begin{array}{l}\text { Biomerieux } \\
\text { Merck } \\
\text { Biomerieux } \\
\text { Biomerieux } \\
\text { Biomerieux }\end{array}$ \\
\hline & Others, with pyridoxal-5-phosphate & $\operatorname{Dax} 72$ & Bayer \\
\hline & $\begin{array}{l}\text { Acc. to SFBC/IFCC } \\
\text { (without pyridoxal-5-phosphate) }\end{array}$ & $\begin{array}{l}\text { AU } 510 \text { (1) } \\
\text { Hitachi } 717 \text { (1) - Hitachi } 737 \text { - Hitachi } 747 \\
\text { Monarch (1), (2) } \\
\text { Wako } 30 \mathrm{R}\end{array}$ & $\begin{array}{l}\text { Merck } \\
\text { Boehringer } \\
\text { Instrumentation Lab. } \\
\text { Serono }\end{array}$ \\
\hline \multirow[t]{2}{*}{$\begin{array}{l}\text { Alkaline } \\
\text { phosphatase }\end{array}$} & $\begin{array}{l}\text { Acc. to SFBC/IFCC } \\
\text { (with amino-methyl- } \\
\text { propanol buffer) }\end{array}$ & $\begin{array}{l}\text { AU } 510(2) \\
\text { AU } 5010(1) \\
\text { AU } 5000(2) \\
\text { CX } 7(1),(2) \\
\text { Dax } 72 \\
\text { Hitachi } 717(2)-\text { Hitachi } 737-\text { Hitachi } 747 \\
\text { Open } 30(1) \\
\text { Open } 30(2)\end{array}$ & $\begin{array}{l}\text { Biomerieux } \\
\text { Boehringer } \\
\text { Merck } \\
\text { Biomerieux } \\
\text { Bayer } \\
\text { Boehringer } \\
\text { Boehringer } \\
\text { Biomerieux }\end{array}$ \\
\hline & $\begin{array}{l}\text { Acc. to DGKC } \\
\text { (with diethanolamine buffer) }\end{array}$ & $\begin{array}{l}\text { AU } 510(1) \\
\text { Hitachi } 717(1) \\
\text { Wako } 30 \mathrm{R}\end{array}$ & $\begin{array}{l}\text { Merck } \\
\text { Biomerieux } \\
\text { Serono }\end{array}$ \\
\hline \multirow[t]{2}{*}{$\alpha$-Amylase } & Maltotetraose & $\mathrm{CX} 7(2)$ & Biomerieux \\
\hline & PNP-G7 & $\begin{array}{l}\text { AU } 510(1) \\
\text { AU } 510(2) \\
\text { CX } 7(1) \\
\text { Hitachi } 717(1)-\text { Hitachi } 747 \\
\text { Hitachi } 717(2)-\text { Hitachi } 737 \\
\text { Monarch (1) } \\
\text { Open } 30(1),(2) \\
\text { Wako } 30 \mathrm{R}\end{array}$ & $\begin{array}{l}\text { Merck } \\
\text { Biomerieux } \\
\text { Biomerieux } \\
\text { Boehringer } \\
\text { Biomerieux } \\
\text { Instrumentation Lab. } \\
\text { Biomerieux } \\
\text { Serono }\end{array}$ \\
\hline \multirow[t]{2}{*}{ Creatine kinase } & $\begin{array}{l}\text { N-Acetylcysteine activated, } \\
\text { acc. to DGKC/SFBC }\end{array}$ & $\begin{array}{l}\text { AU } 510(1)-\text { AU } 5000(2) \\
\text { AU } 510(2) \\
\text { CX } 7(1),(2) \\
\text { Dax } 72 \\
\text { Hitachi } 717 \text { (1) } \\
\text { Hitachi } 717(2) \text { - Hitachi } 737 \text { - Hitachi } 747 \\
\text { Monarch (1) } \\
\text { Open } 30(1),(2)\end{array}$ & $\begin{array}{l}\text { Merck } \\
\text { Biomerieux } \\
\text { Biomerieux } \\
\text { Bayer } \\
\text { Biomerieux } \\
\text { Boehringer } \\
\text { Instrumentation Lab. } \\
\text { Biomerieux }\end{array}$ \\
\hline & $\mathrm{N}$-Acetylcysteine activated, others & Wako $30 \mathrm{R}$ & Serono \\
\hline \multirow[t]{3}{*}{$\begin{array}{l}\gamma \text {-Glutamyl } \\
\text { transferase }\end{array}$} & $\begin{array}{l}\text { Carboxylated substrate, } \\
\text { acc. to IFCC }\end{array}$ & $\begin{array}{l}\text { Hitachi } 717(2) \\
\text { Monarch (1) }\end{array}$ & $\begin{array}{l}\text { Eurodiag. } \\
\text { Instrumentation Lab. }\end{array}$ \\
\hline & Carboxylated substrate, others & $\begin{array}{l}\text { AU } 510(2),(2) \text { - AU } 5010 \text { (1) - AU } 5000 \text { (2) } \\
\text { Hitachi } 717(1),(3) \text { - Hitachi } 737 \text { - Hitachi } 747\end{array}$ & $\begin{array}{l}\text { Merck } \\
\text { Boehringer }\end{array}$ \\
\hline & Non-carboxylated substrate & $\begin{array}{l}\text { CX } 7(1),(2) \\
\text { Dax } 72 \\
\text { Open } 30(1),(2) \\
\text { Wako } 30 \mathrm{R}\end{array}$ & $\begin{array}{l}\text { Biomerieux } \\
\text { Bayer } \\
\text { Biomerieux } \\
\text { Serono }\end{array}$ \\
\hline \multirow[t]{3}{*}{$\begin{array}{l}\text { Lactate } \\
\text { dehydrogenase }\end{array}$} & Acc. to DGKC & $\begin{array}{l}\text { AU } 510(1) \\
\text { Hitachi } 717(1)-\text { Hitachi } 747 \\
\text { Monarch (1) }\end{array}$ & $\begin{array}{l}\text { Merck } \\
\text { Boehringer } \\
\text { Instrumentation Lab. }\end{array}$ \\
\hline & Acc. to SFBC & $\begin{array}{l}\text { AU } 510(2)-\text { AU } 5000(2) \\
\text { CX } 7(1) \\
\text { Hitachi } 717(2) \\
\text { Hitachi } 737 \\
\text { Open } 30(1) \\
\text { Open } 30(2)\end{array}$ & $\begin{array}{l}\text { Biomerieux } \\
\text { Biotrol } \\
\text { Biomerieux } \\
\text { Boehringer } \\
\text { Biotrol } \\
\text { Biomerieux }\end{array}$ \\
\hline & Others & CX $7(2)$ & Beckman \\
\hline
\end{tabular}


Tab. 4 Range of concentration or activity of plasma pools to be spiked.

For enzyme activities, expressed in multiples of the upper limit of reference values $(\mathrm{N})$.

\begin{tabular}{llcl}
\hline & Unit & $\begin{array}{c}\text { Range of } \\
\text { concentration } \\
\text { or activity }\end{array}$ \\
\hline Albumin & $\mathrm{g} / \mathrm{mmol} / \mathrm{l}$ & $25 \mathrm{to} 40$ \\
Calcium & 2.00 to 2.50 \\
Cholesterol & $\mathrm{mmol} / \mathrm{l}$ & 4.0 to 5.0 \\
Creatinine & $\mu \mathrm{mol} / \mathrm{l}$ & 200 to 250 \\
Glucose & $\mathrm{mmol} / \mathrm{l}$ & 5.0 to 7.0 \\
Iron & $\mu \mathrm{mol} / \mathrm{m}$ & 15.0 to 25.0 \\
Magnesium & $\mathrm{mmol} / \mathrm{l}$ & 0.75 to 1.00 \\
Phosphorus & $\mathrm{mmol} / \mathrm{l}$ & 1.00 to 1.50 \\
Proteins & $\mathrm{g} / \mathrm{l}$ & $55 \mathrm{to} 75$ \\
Total bilirubin & $\mu \mathrm{mol} / 1$ & 40 to 50 \\
Triacylglycerols & $\mathrm{mmol} / \mathrm{l}$ & 1.20 to 1.80 \\
Urea & $\mathrm{mmol} / \mathrm{l}$ & 12.0 to 18.0 \\
Uric acid & $\mu \mathrm{mol} / \mathrm{l}$ & 200 to 300 \\
$\alpha$-Amylase & $\mathrm{N}$ & 1.5 to 2.5 \\
Alanine amino transferase & $\mathrm{N}$ & 1.5 to 2.5 \\
Alkaline phosphatase & $\mathrm{N}$ & 1.5 to 2.5 \\
Aspartate amino transferase & $\mathrm{N}$ & 1.5 to 2.5 \\
Creatine kinase & $\mathrm{N}$ & 1.5 to 2.5 \\
$\gamma$-Glutamyl transferase & $\mathrm{N}$ & 1.5 to 2.5 \\
Lactate dehydrogenase & $\mathrm{N}$ & 1.5 to 2.5 \\
\hline
\end{tabular}

evaluators were asked to pay special attention to the following points: running the tests in duplicate and adding the supplement material just prior to testing to avoid any transformation of the interfering substance.

\subsection{Calculation of results}

Final results were calculated by MacVALTEC 3.0 software $(J . C$. Eynard, D. Grafmeyer) running on an Apple Macintosh worksta- tion on the basis of the measurements' average. If the results from 2 sites did not agree, i. e. if the difference between the two results was greater than or equal to twice the used acceptable limit (tab. 5), they were rechecked (of 83 values involved, 40 were corrected) by the two involved sites.

\section{Results}

\subsection{Results by instrument}

Firstly, we drew up "interferographs" as indicated in the VALTEC protocol with the concentration of interference on the $x$-axis (concentrations of bilirubin and haemoglobin, turbidity index), and the difference between the results of the pool and the spiked specimen expressed in \% of the pool concentration on the $y$-axis.

As stated above, we split the tests into 2 groups, "chemistries" and "enzymes". Taking the 4 different interferences into consideration (bilirubin and ditauro-bilirubin, haemolysis and turbidity), we find we have 1 or 2 graphs per interference per group, i.e. 12 graphs per analyser which leads to more than 250 graphs in total. On each graph, we have indicated the "acceptable limits" as given by the VALTEC protocol (tab. 3). Note, howevere, that the protocol does not stipulate values for albumin or amylase.

Having drawn up the graphs, we then summarised the data in the form of 3 tables (tab. 6, 7, 8). Table 6 shows the results for total and ditauro-bilirubin; note the relationship between the 2 types of interference, the lack of interference for enzyme activities measurements, and above the very frequent interference shown for choles-

Tab. 5 Acceptable limits (according to SFBC-VALTEC guidelines) except for albumin and $\alpha$-amylase.

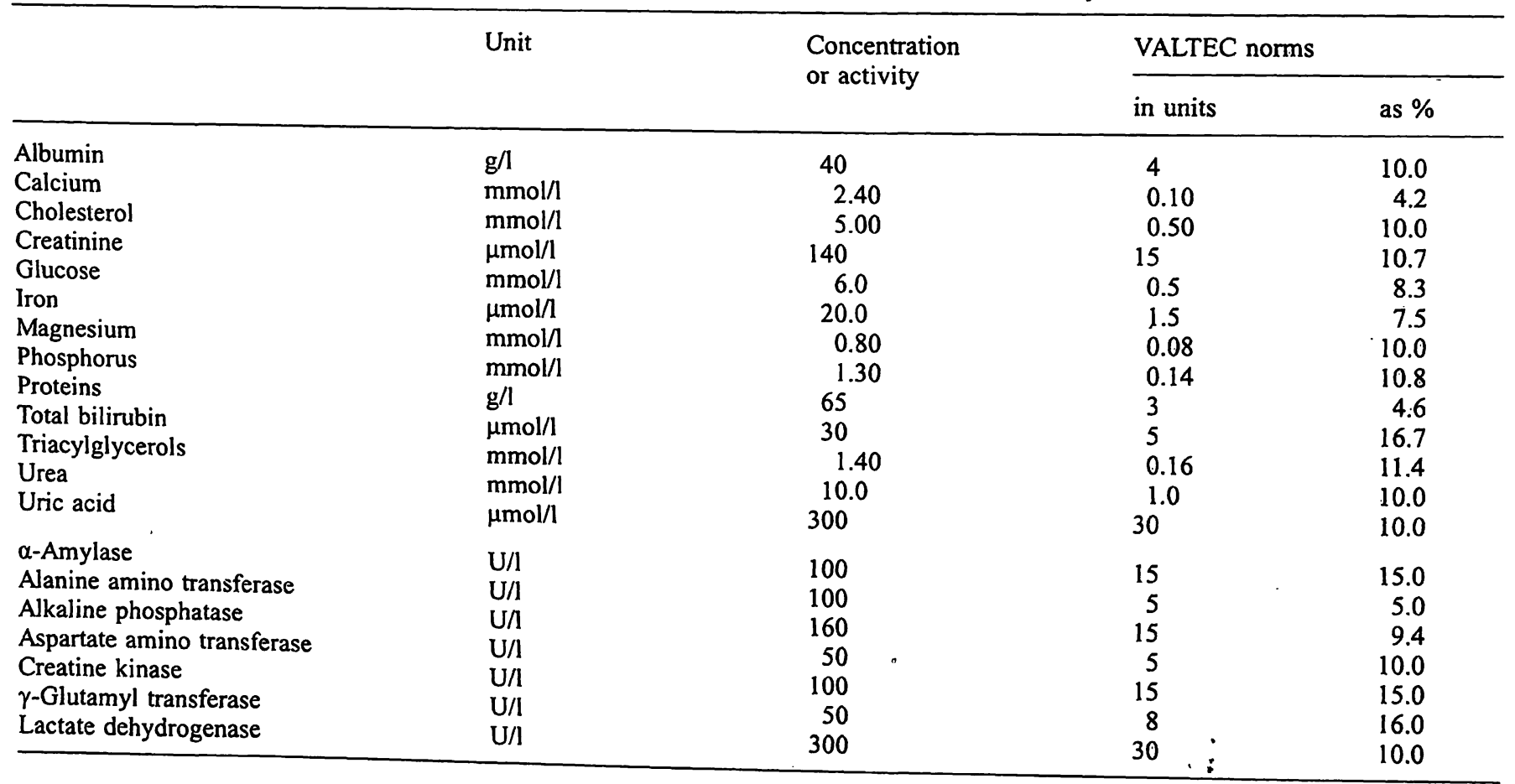


terol, creatinine, glucose, phosphorus, total proteins, triacylglycerols and uric acid determinations. Table 7 shows the results for haemolysis; note that haemolysis does interfere very frequently on chemistries determinations, particularly for iron, phosphorus, total proteins, bilirubin and uric acid as for the measurement of the activities of alkaline phosphatases and creatine kinase. Table 8 shows the results for turbidity. Note its less frequent interference; hardly ever on enzyme activities measurements, and only on some chemistries: e.g. glucose, iron, phosphorus, total proteins, bilirubin and uric acid.

\subsection{Overall results per analyte}

We also drew up "interferographs" per analyte with the results of several instruments for the same analyte, with the concentration of interference (concentrations of bilirubin and haemoglobin, turbidity index) of the x-axis, and the difference between the results of the pool and the spiked specimen expressed in concentration on the $y$-axis. Some representative examples of these graphs are shown (fig. 1, 2, 3).

In table 9 , the results of the tests have been grouped together by analyte. The number of tests carried out $(N)$ and the number of times an interference was seen at the highest level of addition are shown. This provides at least 2 types of information: the substance which interferes most often, and the analyte(s) which is (are) most sensitive to interference. In this way, 1443 tests were performed for which 324 interferences were noted, i. e. $22.5 \%$. Haemolysis interferes the most often: in 348 tests, 120 were affected (34.5\%). Total bilirubin interferes in $21.7 \%$ of cases (84 times out of 387 tests).

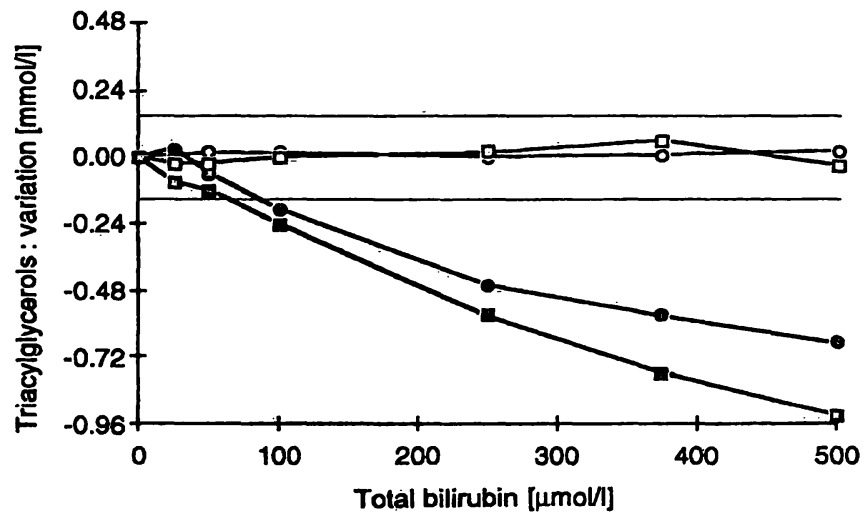

Fig. 1 Example of interferograph: the influence of bilirubin on triacylglycerols measurement.

In that case, the interference depends on the method used: with the enzymatic method with $340 \mathrm{~nm}$ readings on the Open 30 (1) and Chem (1) analysers, there is no interference; and with the enzymatic peroxidase methods on the Open 30 (2) et CX 7 (2) analysers, the interference is significant.

-O- Open 30 (1); - - Open 30 (2); - - - Chem l (1); - - CX 7 (2)

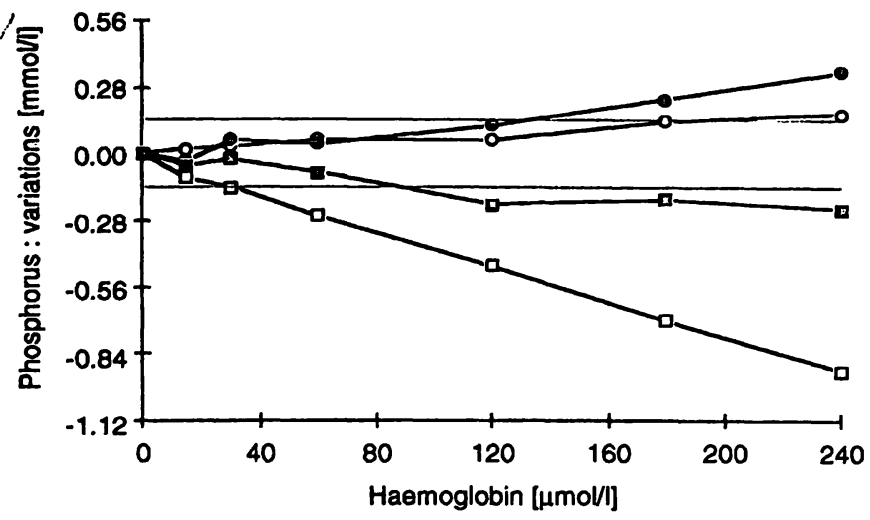

Fig. 2 Example of interferograph: the influence of haemolysis on phosphorus measurement.

All the analysers use the same method: phosphomolybdate with $340 \mathrm{~nm}$ readings; a close examination of the operating conditions may help to explain, at least partly, the results.

-O- AU 510 (1); -0- CX 7 (1); - - Dimension (1); Paramax (1)

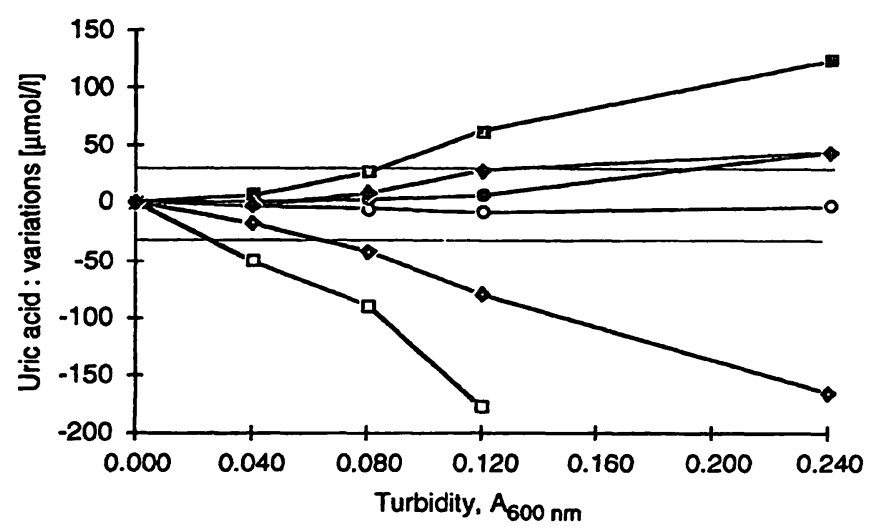

Fig. 3 Example of interferograph: the influence of turbidity on uric acid measurement.

The shown interference are not dependent on the methods: the Chem 1 (2) and the AU 510 (2) work with an "uricase/catalase/ dehydrogenase" method, the other analysers with "uricase/peroxidase" methods.

-O- AU 510 (1); - $\square-$ Chem 1 (1); - $\diamond$ Monarch (2)

-o- AU 510 (2); - - - Dax 72; - $\diamond$ Paramax (1)

Ditauro-bilirubin causes less interference, $16.7 \%$ (53 of 317 tests), but the concentrations were not as high, 250 $\mu \mathrm{mol} / \mathrm{l}$ as opposed to $500 \mu \mathrm{mol} / \mathrm{l}$ for total bilirubin. For turbidity, interference was seen in 67 of 391 tests (17.1\%).

The sensitivity to interference was not the same for all analytes; they can be divided up into 3 groups:

- slightly sensitive or not at all sensitive: in this group, less than $10 \%$ of specimens showed interference according to the norms of the protocol: urea, $\alpha$-amylase, $\gamma$-glutamyl transferase, lactate dehydrogenase and alkaline phosphatase.

- fairly sensitive: in this group, a significant interference was seen in 10 to $20 \%$ of cases noted as indicated in the protocol: albumin, calcium, magnesium. aspartate aminotransferase and creatine kinase. 


\begin{tabular}{|c|c|c|c|c|c|c|c|c|c|}
\hline نُّ & $\cdots-$ & 0000 & -100 & $00-1$ & $000-$ & -- & o- స్$_{1}^{\circ}$ & 0000 & $0000 \ldots$ \\
\hline 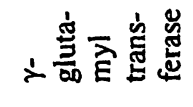 & $\cdots-\cdots$ & 0000 & 0000 & 0000 & $000-$ & 00 & $0-00$ & 0000 & 0000 \\
\hline 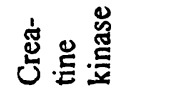 & $\cdots-$ & 0000 & -00 & $00-1$ & $000-$ & 00 & $0-00$ & 0060 & $0000-$ \\
\hline 方害总 & $\cdots$ & 0000 & $\cdots-\cdots$ & $00-1$ & $000-$ & - & -100 & 0000 & $0000-$ \\
\hline 蒫导㝘吾导 & $\cdots-\cdots$ & 0000 & 0000 & 0000 & $000-$ & 00 & $0-00$ & 0000 & $0000-$ \\
\hline 岕高它总 & $-\cdots$ & 0000 & -00 & 0000 & 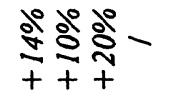 & 00 & $0-\frac{\alpha^{\circ}}{i} 0$ & 0000 & $000 \stackrel{\mathrm{i}}{1}-1$ \\
\hline 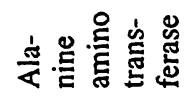 & $-\cdots$ & 0000 & -100 & 0000 & $000-$ & $\stackrel{\stackrel{0}{0} 0}{1}$ & $0-00$ & 0000 & $000 \frac{8}{1}-1$ \\
\hline$\frac{\mathbb{5}}{5}$ & 0000 & $00-1$ & -100 & 0000 & $000-$ & 00 & $0-00$ & 0000 & 00001 \\
\hline 은 & $\cdots$ & 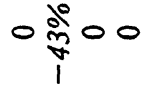 & ํํํำ & 0000 & $000-$ & ஓे̀ & $0-00$ & 0000 & 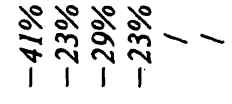 \\
\hline 它窟突品啹 & $\cdots-1$ & 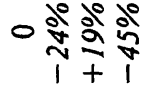 & o ìं - & 0000 & $-\underset{1}{\stackrel{0}{0}-}$ & 00 & -00 & 0000 & -100 \\
\hline$\dot{s}$ & 8ి000 & $00-$ & ì & 0000 & 0080 & 00 & 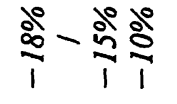 & 0000 & 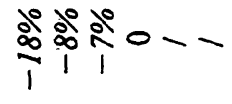 \\
\hline 容 & $\cdots-$ & 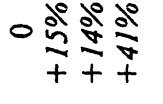 & 0000 & - & ० ํำ & ○ & 犬े̀- & 0000 & 通000- \\
\hline 莺施 & $\cdots$ & 0000 & -00 & $00-1$ & $000-$ & - & - - ํํำ & -100 & - \\
\hline 혼 & $-\cdots$ & 0000 & $-\cdots$ & $00 \underset{\frac{7}{\pi}}{+}$ & $-10-$ & $\cdots$ & o- & -100 & $-\frac{\frac{d}{t}}{t} 000$ \\
\hline 言 & 0000 & 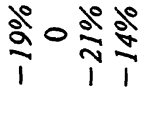 & 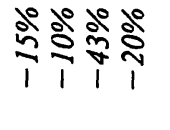 & 0000 & $000-$ & ลें & 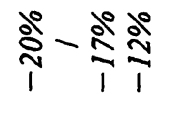 & 0000 & 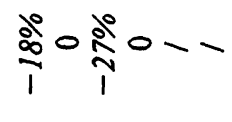 \\
\hline હٌّ & 0000 & $00-1$ & - $0 \stackrel{\text { ลे }}{1}$ & 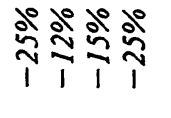 & $00 \stackrel{\text { Iิ }}{10}$ & సิํํำ & เి- ถి० & 0000 & iิ \\
\hline 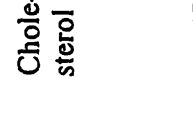 & $x-$ & 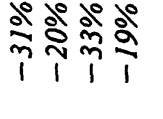 & ๙ิำ & 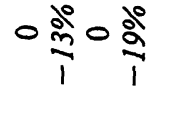 & $-\frac{\frac{d}{2}}{1}-$ & م. 유 & ঠ্লি - & 0000 & - - \\
\hline 厄ँ & 0000 & $00-1$ & 0000 & 0080 & $000-$ & 00 & $0-00$ & 0000 & $\$_{1}^{\circ} 00000$ \\
\hline 㐔. & $x-$ & $\cdots-$ & & $00-1$ & $--\frac{d i}{i}-$ & -- & - & - & 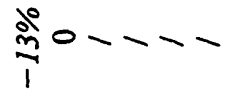 \\
\hline & $\Xi \approx$ & $\lesssim \lesssim$ & $\lesssim \approx$ & $\lesssim \approx$ & $\widehat{\Xi} \widehat{d}$ & $\widehat{\Xi}$ & $\widehat{\approx}$ & $\lesssim \approx$ & $\widehat{\Xi} \widehat{\equiv} \widehat{్}$ \\
\hline & $\begin{array}{l}\infty \\
\mathbb{5} \\
\text { 昰 }\end{array}$ & $\begin{array}{l}\frac{0}{n} \\
2 \\
2\end{array}$ & 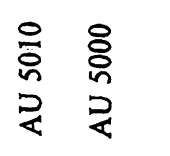 & $\begin{array}{l}\bar{\xi} \\
\bar{\delta}\end{array}$ & ⿵ં & $\begin{array}{l}\tilde{a} \\
\stackrel{x}{\pi}\end{array}$ & 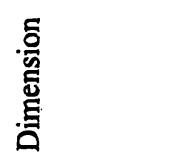 & 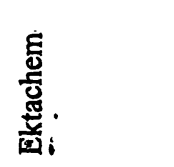 & 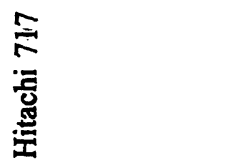 \\
\hline
\end{tabular}




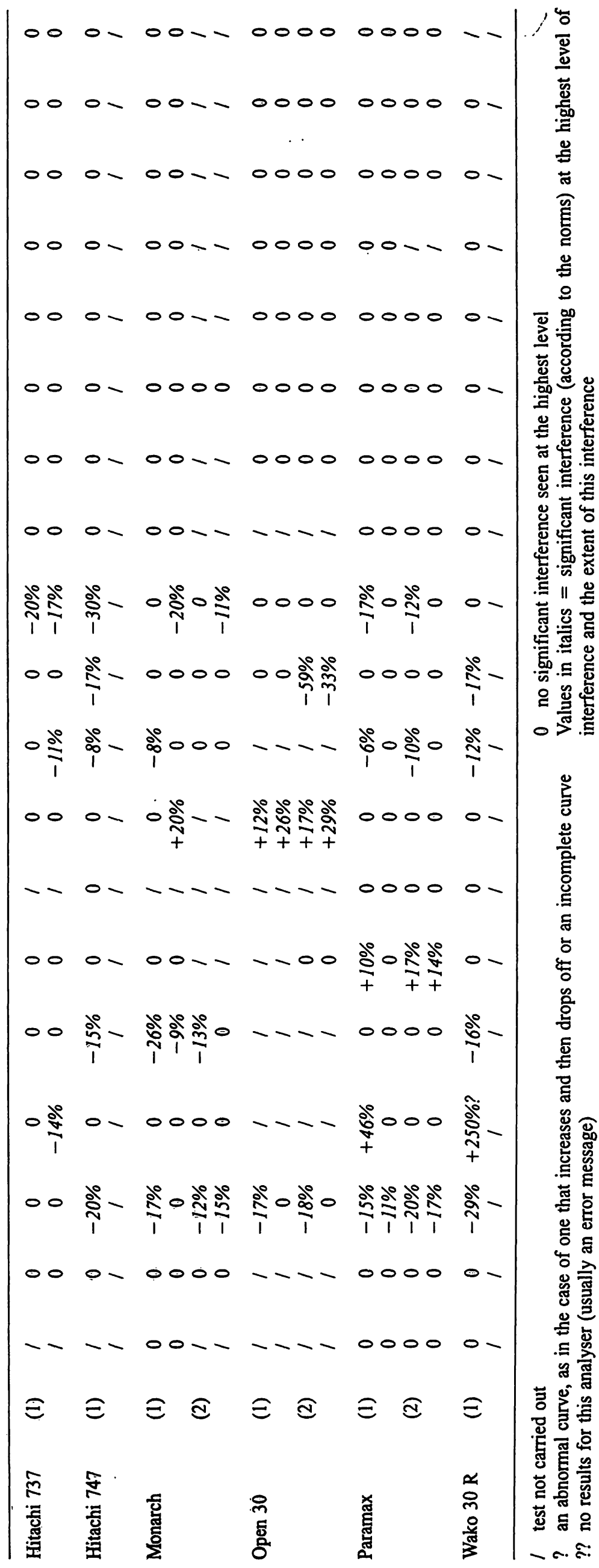




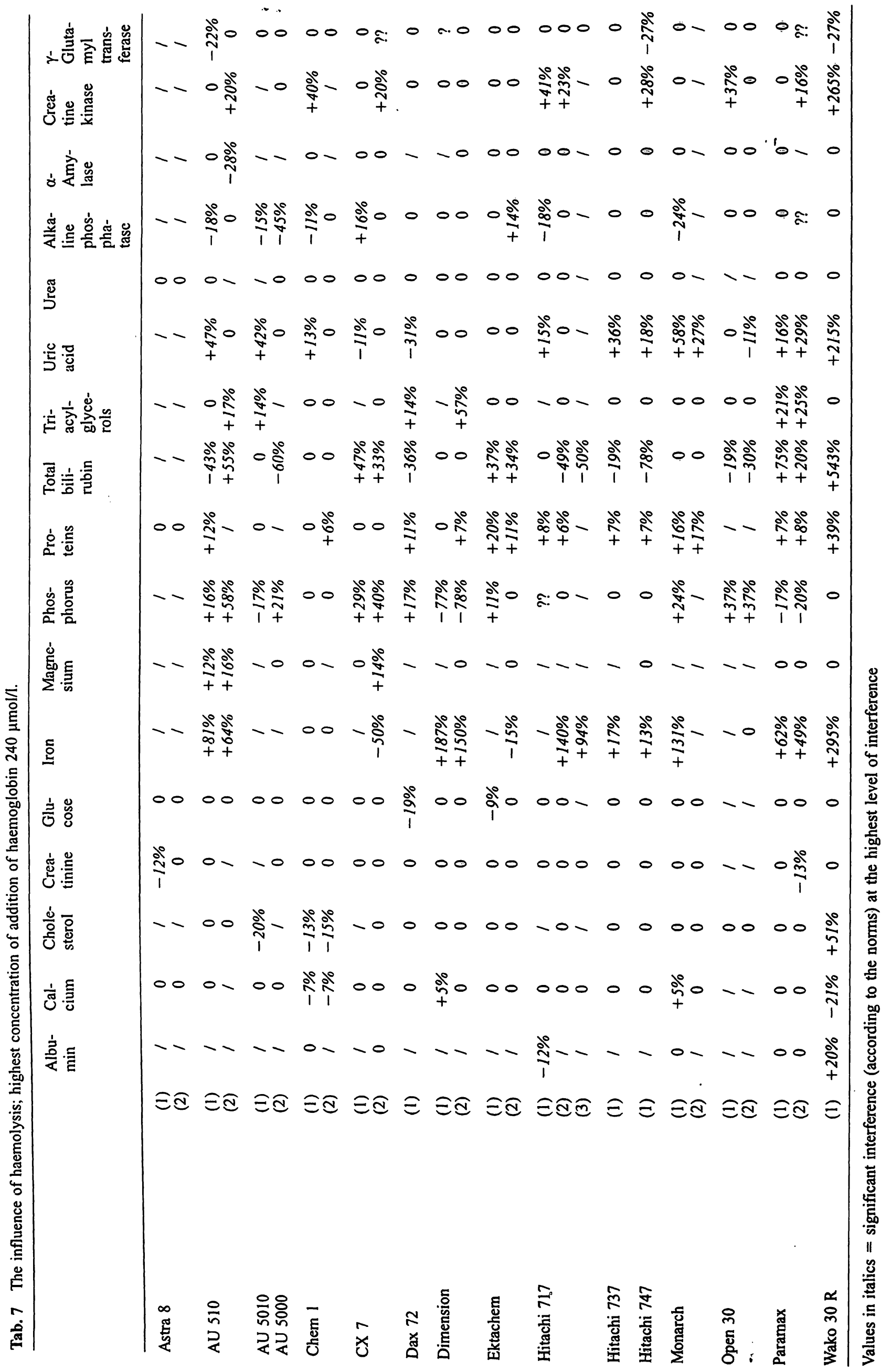




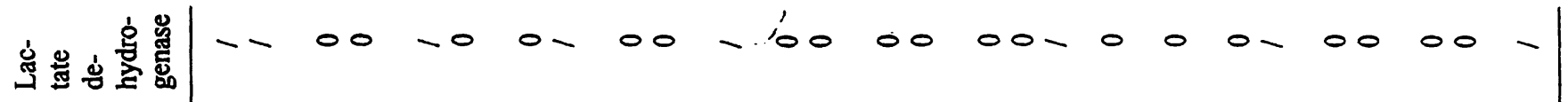

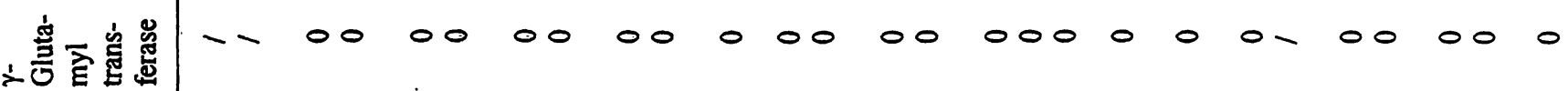
岕若 W

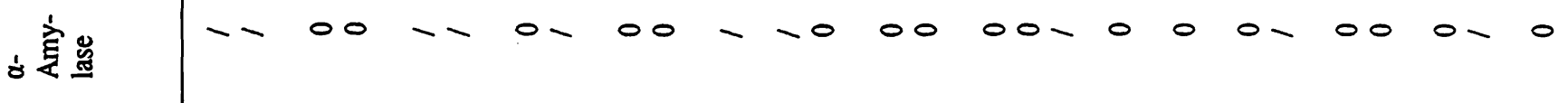

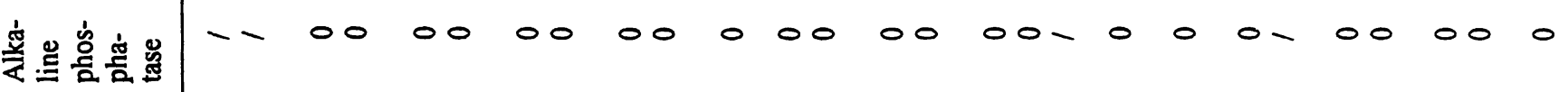

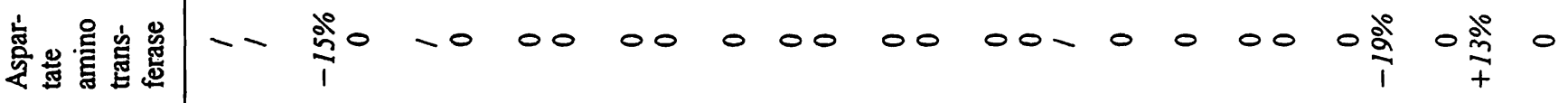

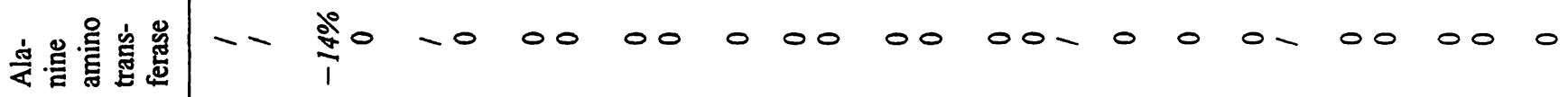
ङ

은 응 $000-100000000000-0000$

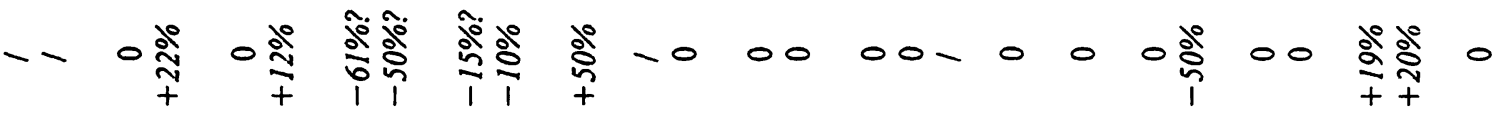
要狺热

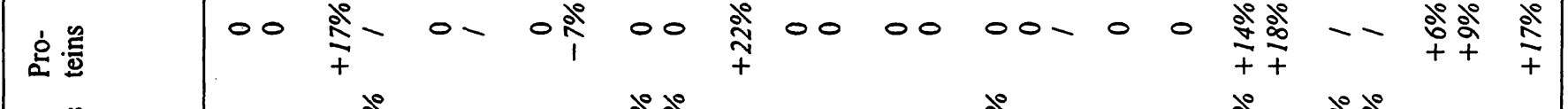

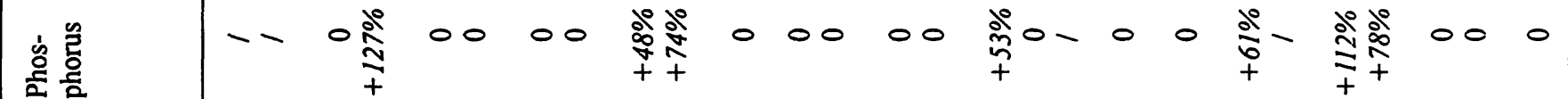
峁

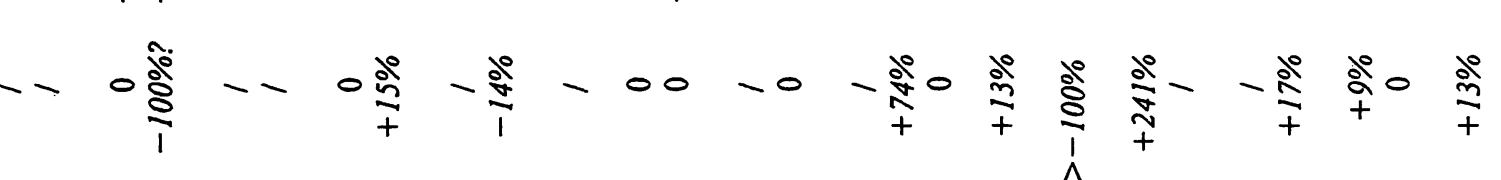
을

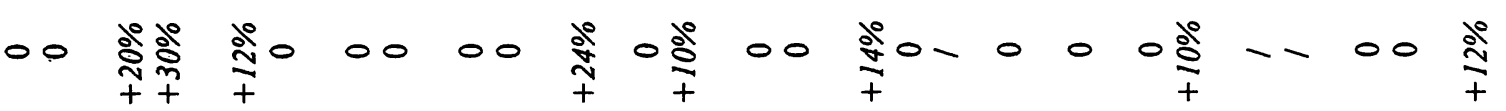

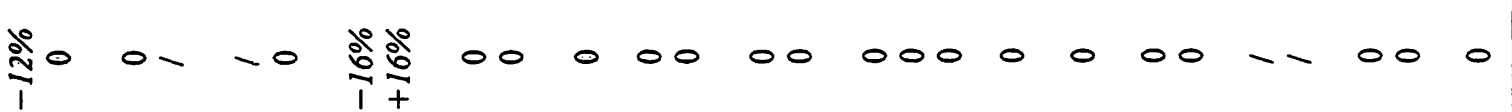
冚

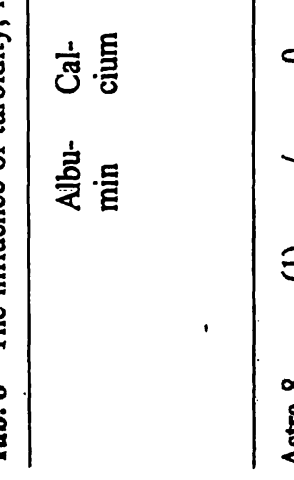

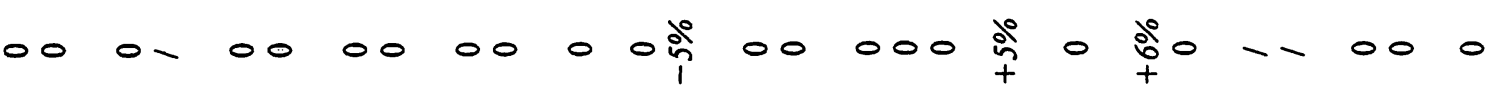

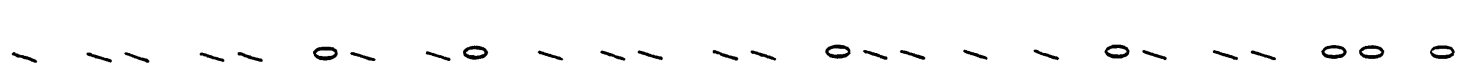

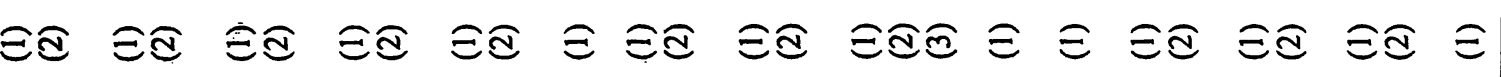

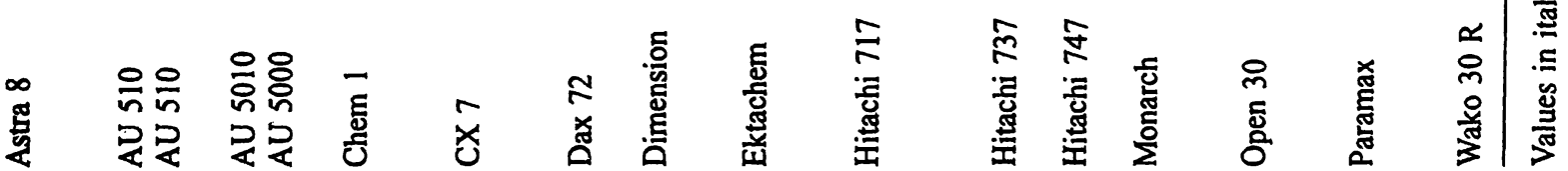


Tab.9 Quantitative analysis of results : $N$ : number of tests carried out - $n$ : number of interferences found (at the highest level of addition).

\begin{tabular}{|c|c|c|c|c|c|c|c|c|c|c|}
\hline & \multicolumn{2}{|c|}{ Bilirubin } & \multicolumn{2}{|c|}{ Ditaurobilirubin } & \multicolumn{2}{|c|}{ Haemolysis } & \multicolumn{2}{|c|}{ Turbidity } & \multicolumn{2}{|c|}{ Total interferences } \\
\hline & $N$ & $\mathbf{n}$ & $\mathbf{N}^{*}$ & $\mathrm{n}$ & $\mathrm{N}$ & $\mathbf{n}$ & $\mathbf{N}$ & $\mathrm{n}$ & number & $\%$ \\
\hline \multicolumn{11}{|l|}{ "Chemistry" } \\
\hline Albumin & 7 & 2 & 5 & 0 & 7 & 2 & 7 & 0 & 4 & 15.4 \\
\hline Calcium & 24 & 2 & 20 & 0 & 24 & 5 & 24 & 3 & 10 & 10.9 \\
\hline Cholesterol & 21 & 15 & 17 & 11 & 21 & 4 & 21 & 1 & 31 & 38.8 \\
\hline Creatinine & 23 & 10 & 19 & 7 & 23 & 2 & 23 & 3 & 22 & 25.0 \\
\hline Glucose & 24 & 13 & 20 & 6 & 24 & 2 & 24 & 8 & 29 & 31.5 \\
\hline Iron & 17 & 4 & 13 & 1 & 17 & 14 & 17 & 10 & 29 & 45.3 \\
\hline Magnesium & 12 & 1 & 9 & 1 & 12 & 3 & 12 & 3 & 8 & 17.8 \\
\hline Phosphorus & 23 & 6 & 19 & 8 & 23 & 15 & 23 & 7 & 36 & 40.9 \\
\hline Proteins & 22 & 12 & 18 & 4 & 22 & 15 & 22 & 8 & 39 & 46.4 \\
\hline Total bilirubin & I & 1 & l & I & 25 & 17 & 25 & 9 & 26 & 52.0 \\
\hline Triacylglycerols & 20 & 5 & 17 & 4 & 20 & 6 & 1 & l & 15 & 26.3 \\
\hline Urea & 21 & 0 & 17 & 0 & 21 & 0 & 21 & 0 & 0 & 0.0 \\
\hline Uric acid & 24 & 9 & 20 & 8 & 24 & 14 & 23 & 10 & 41 & 45.1 \\
\hline \multicolumn{11}{|l|}{ Enzyme } \\
\hline$\alpha$-Amylase & 17 & 0 & 14 & 0 & 17 & 1 & 17 & 0 & 1 & 1.5 \\
\hline Alanine amino transferase & 23 & 1 & 19 & 1 & 1 & 1 & 23 & 1 & 3 & 4.6 \\
\hline Alkaline phosphatase & 23 & 0 & 19 & 0 & 23 & 8 & 23 & 0 & 8 & 9.1 \\
\hline Aspartate amino transferase & 22 & 3 & 18 & 2 & 1 & 1 & 22 & 3 & 8 & 12.9 \\
\hline Creatine kinase & 21 & 0 & 17 & 0 & 21 & 9 & 21 & 1 & 10 & 12.5 \\
\hline$\gamma$-Glutamyl transferase & 24 & 0 & 20 & 0 & 24 & 3 & 24 & 0 & 3 & 3.3 \\
\hline Lactate dehydrogenase & 19 & 1 & 16 & 0 & 1 & 1 & 19 & 0 & 1 & 1.9 \\
\hline Total & 387 & $\begin{array}{l}84 \\
21.7 \%\end{array}$ & 317 & $\begin{array}{l}53 \\
16.7 \%\end{array}$ & 348 & $\begin{array}{l}120 \\
34.5 \%\end{array}$ & 391 & $\begin{array}{l}67 \\
17.1 \%\end{array}$ & $\begin{array}{r}1443 \\
324\end{array}$ & $22.5 \%$ \\
\hline
\end{tabular}

- very sensitive: in this group, interference occurred in more than $20 \%$ of cases: creatinine: $25 \%$ - triacylglycerols: $26.3 \%$ - glucose: $31.5 \%$ - cholesterol: $38.8 \%$ - phosphorus: $40.9 \%$ - uric acid: $45.1 \%$ iron: $45.3 \%$ - total proteins: $46.4 \%$ - total bilirubin: $52.0 \%$.

\section{Discussion}

\subsection{What can be ascertained?}

The interference can be placed into 3 categories: interference by addition, chemical interference and spectral interference.

\subsubsection{Interferences by addition}

In this case, visible interference occurs due to the addition of external substances which increase the apparent amount of analyte. Typically, haemoglobin falls into this category, being an indicator of red cell lysis $(2,3)$; the contents of the red cells will subsequently be found in the plasma, modifying its composition. Several of the analytes tested are affected in this way: red cells are rich in enzymes which will prevent correct readings if specimens are haemolysed (lactate dehydrogenase, transaminases). They are also rich in organic phosphate esters; thus the added amount can increase by up to $20 \%$; in practice, this is not always found.

Haemoglobin is potentially a rich source of iron. However, the iron-porphyrin bonding is stronger than the bonding for the usual transport protein (transferrin), which means that releasing iron for tests can be adapted to avoid interference. This appears to be the case, as although $82 \%$ of tests were affected, this had nothing to do with an increase in iron (fig. 4). Some tests were

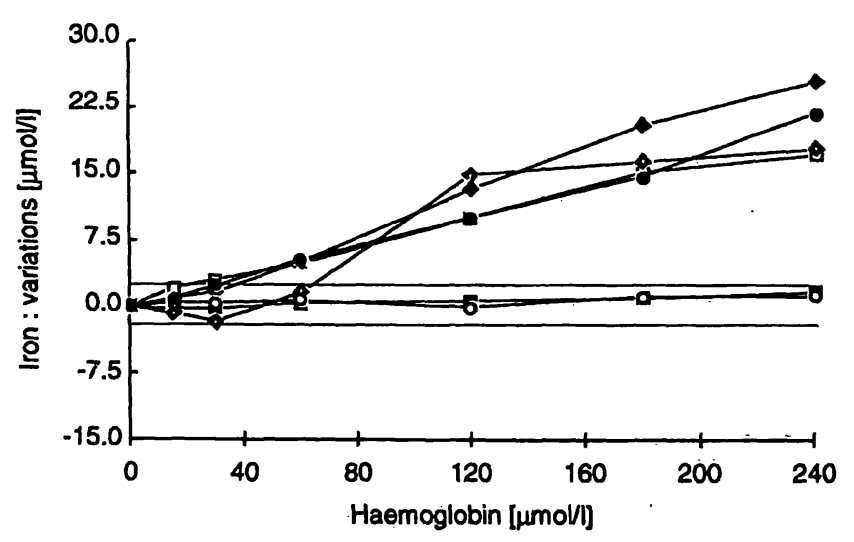

Fig. 4 The influence of haemolysis on iron measurement; because of its magnitude, the interference is not due to the release of iron from haemoglobin, but it probably has a spectral origin. - - AU 510 (1); - $\diamond$ Hitachi 717 (3); - - - Open 30 (2) -n-Chem 1 (2); - Dimension (1); - - Hitachi 717 (2) 
negatively influenced ( 2 cases, $2 \%$ ). This suggests spectral interference.

Haemoglobin is also a protein which will also increase the plasma content in $68 \%$ of cases. Despite the fact that the added amount is small (maximum addition, 240 $\mu \mathrm{mol} / \mathrm{l}$, approximately $3.8 \mathrm{~g} / 1$ for $70 \mathrm{~g} / \mathrm{l}$ ) this is still significant (protocol norm: $3 \mathrm{~g} / 1$ for $65 \mathrm{~g} / \mathrm{l}$, tab. 5). In certain cases, the interference was increased even more due to additional spectral interference.

The concentration of erythrocytic magnesium is around 3 times greater than plasmatic values. This, therefore, causes increases in $25 \%$ of the cases, which is nevertheless negligible as the concentration of haemolysis needs to be far greater than the concentration used in the study to have an effect.

Creatinine kinase is strongly affected: in $43 \%$ of the cases the value increased, whereas with bilirubin and turbidity, virtually no difference can be seen. This is probably due to erythrocytic adenylate kinase which is not wholly inhibited under operating conditions (reagents contain adenosine monophosphate or diadenosine phosphate or a combination of the two).

\subsubsection{Spectral interference}

This is based on the law of added absorbances. All substances, other than the measured one, absorbing at the wavelengths used for the test will cause an apparent increase in the measured concentration. However, the substances included in the study have high absorbances

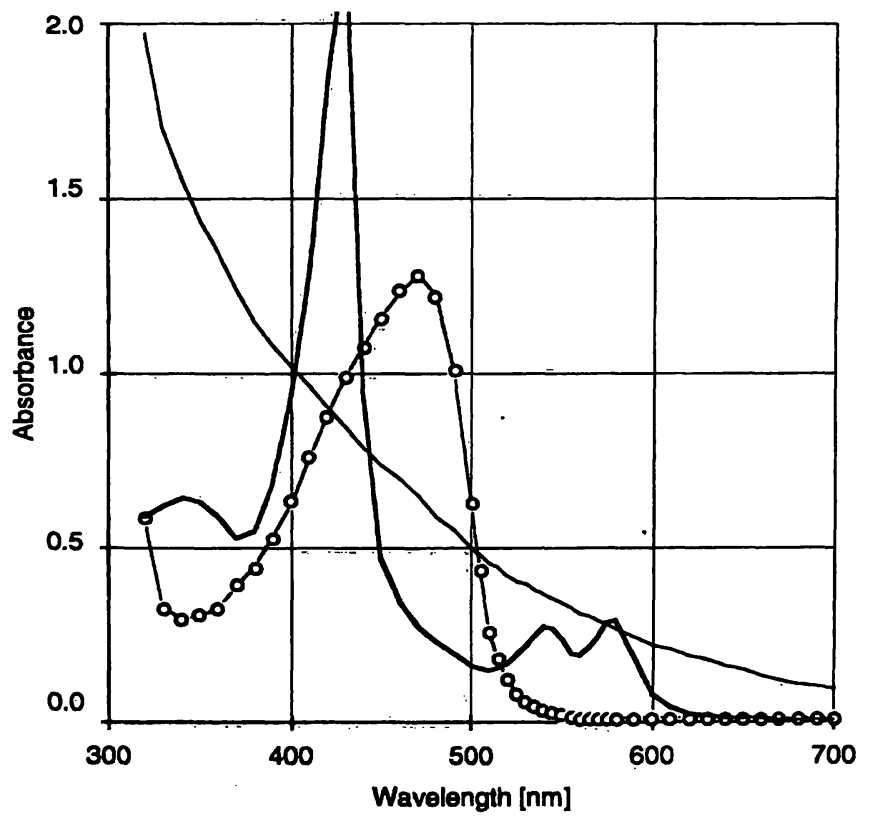

Fig. 5 The spectra of bilirubin, haemoglobin and turbidity compared; they were obtained on a Kontron Uvikon (model 810) double beam spectrophotometer with spiked pools at the highest level of addition, and then diluted $1: 100$ in $150 \mathrm{mmol} / \mathrm{l} \mathrm{NaCl}$.

- - - Bilirubin; - Haemoglobin; - Turbidity /at many different wavelengths (fig. 5) and their spectra may change with the conditions (fig. 6 and 7).

Turbidity will interfere more at shorter wavelengths (Rayleigh's law, fig. 5). An example of this is uric acid measurement (tab. 10) using the uricase-catalase methods which suffer far more interference than the uricase/ peroxidase methods (readings made at $340 \mathrm{~nm}$ and 505 $\mathrm{nm}$, respectively). A further example is phosphorus measurement; nearly all methods use phosphomolybdate at $340 \mathrm{~nm}$. This makes it sensitive to turbidity unless certain solutions are added (tab. 11). Catalytic activity of

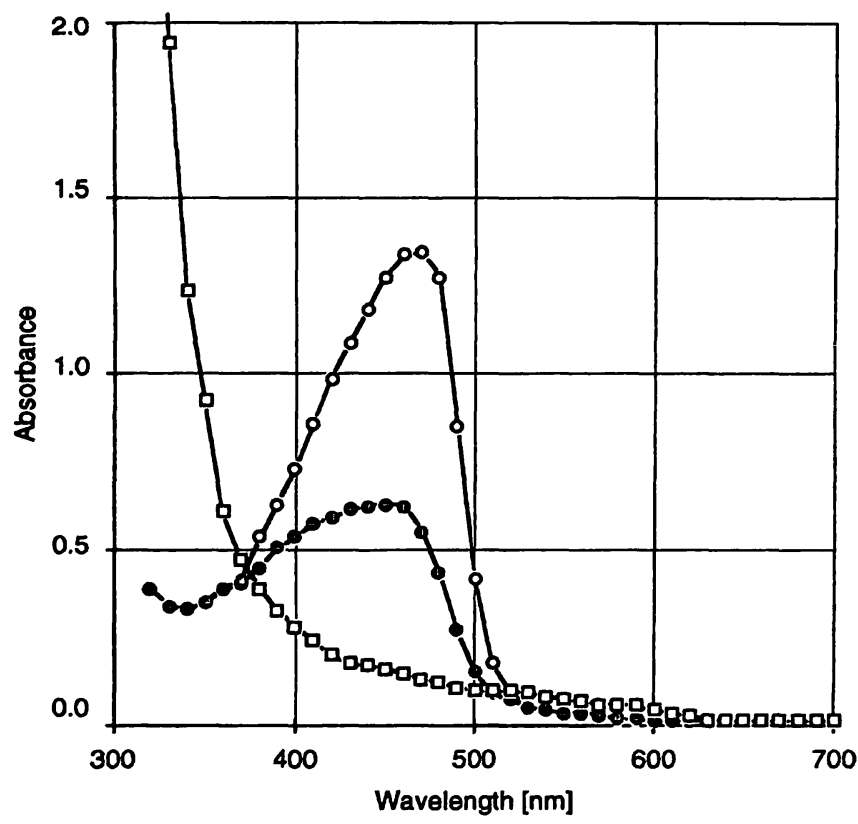

Fig. 6 The comparison of the absorbances of unconjugated bilirubin, conjugated, and unconjugated bilirubin in the presence of an oxidant $\mathrm{H}_{2} \mathrm{O}_{2}$.

Same conditions as fig. 5 .

-O- unconjugated bilirubin

- O- conjugated bilirubin

$-\square-$ unconjugated bilirubin in the present of $\mathrm{H}_{2} \mathrm{O}_{2}$

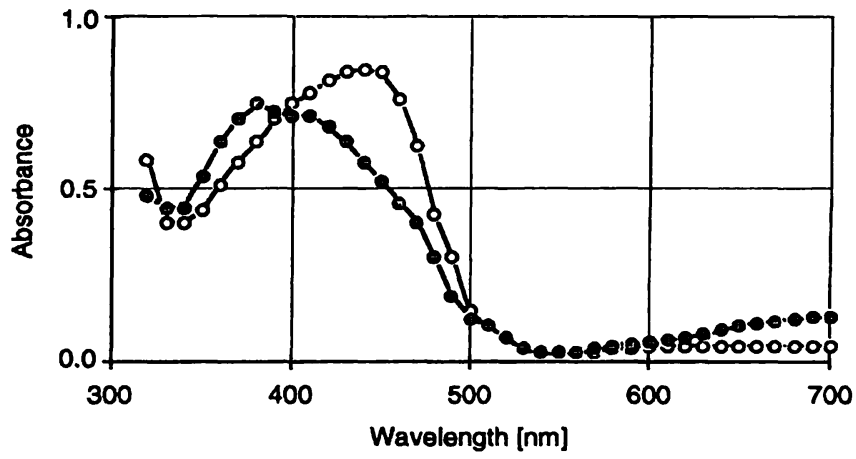

Fig. 7 Comparative absorbances of conjugated bilirubin at pH 1 and $\mathrm{pH} \mathrm{7}$; at acid $\mathrm{pH}$, there is a shift of the spectrum towards the shorter wavelengths.

NB: unconjugated bilirubin does not show differences at different pH values.

Same conditions as fig. 5 .

$-\mathrm{O}-$ conjugated bilirubin at $\mathrm{pH} 7$

- - conjugated bilirubin at $\mathrm{pH} 1$ 
Tab. 10 The influence of turbidity on uric acid measurement.

\begin{tabular}{|c|c|c|}
\hline Method group & Instrument & Turbidity \\
\hline $\begin{array}{l}\text { Uricase/catalase/ } \\
\text { dehydrogenase }\end{array}$ & $\begin{array}{l}\text { AU } 5000(2) \\
\text { AU } 510(2) \\
\text { Chem } 1(1) \\
\text { Chem } 1(2) \\
\text { CX } 7 \text { (1) } \\
\text { CX } 7 \text { (2) } \\
\text { Open } 30(1) \\
\text { Open } 30 \text { (2) }\end{array}$ & $\begin{array}{c}+12 \% \\
+22 \% \\
-61 \% ? \\
-50 \% ? \\
-15 \% ? \\
-10 \% \\
0 \\
0\end{array}$ \\
\hline Uricase/peroxidase & $\begin{array}{l}\text { AU } 5010(1) \\
\text { AU } 510(1) \\
\text { Dax } 72 \\
\text { Hitachi } 717(1) \\
\text { Hitachi } 717(2) \\
\text { Hitachi } 737 \\
\text { Hitachi } 747 \\
\text { Monarch (1) } \\
\text { Monarch (2) } \\
\text { Paramax (1) } \\
\text { Paramax (2) } \\
\text { Wako 30 R }\end{array}$ & $\begin{array}{c}0 \\
0 \\
+50 \% \\
0 \\
0 \\
0 \\
0 \\
0 \\
-50 \% \\
+19 \% \\
+20 \% \\
0\end{array}$ \\
\hline Uricase/reflectometry & $\begin{array}{l}\text { Ektachem (1) } \\
\text { Ektachem (2) }\end{array}$ & $\begin{array}{l}0 \\
0\end{array}$ \\
\hline Uricase $293 \mathrm{~nm}$ & $\begin{array}{l}\text { Dimension (1) } \\
\text { Dimension (2) }\end{array}$ & $\begin{array}{l}1 \\
0\end{array}$ \\
\hline
\end{tabular}

Italic numbers $=$ significant interference (according to the norms) at the highest level of interference

Tab. 11 The influence of turbidity on phosphorus measurement.

\begin{tabular}{llc}
\hline Method group & Instrument & Turbidity \\
\hline \multirow{3}{*}{ Phosphomolybdate } & AU 5000 (2) & 0 \\
measurement at 340 nm & AU 5010 (1) & 0 \\
& AU 510 (1) & 0 \\
& AU 510 (2) & $+127 \%$ \\
& Chem 1 (1) & 0 \\
& Chem 1 (2) & 0 \\
& CX 7 (1) & $+48 \%$ \\
& CX 7 (2) & $+74 \%$ \\
& Dax 72 & 0 \\
& Dimension (1) & 0 \\
& Dimension (2) & 0 \\
& Hitachi 717 (1) & $+53 \%$ \\
& Hitachi 717 (2) & 0 \\
& Hitachi 737 & 0 \\
& Hitachi 747 & 0 \\
& Monarch (1) & $+61 \%$ \\
& Open 30 (1) & $+112 \%$ \\
& Open 30 (2) & $+78 \%$ \\
& Paramax (1) & 0 \\
& Paramax (2) & 0 \\
& Wako 30 R & 0 \\
& Ektachem (1) & 0 \\
Reflectometry & Ektachem (2) & 0 \\
& & \\
& & \\
& & \\
& &
\end{tabular}

Italic numbers = significant interference (according to the norms) at the highest level of interference

enzyme measurement, on the other hand, is not affected unless the signal cannot be correctly measured when absorbance becomes too high at $340 \mathrm{~nm}$.
Tab. 12 The influence of bilirubin on creatinine measurement for methods using the Jaffé reaction.

\begin{tabular}{lccl}
\hline Instrument & Bilirubin & $\begin{array}{l}\text { Ditauro- } \\
\text { bilirubin }\end{array}$ & $\begin{array}{l}\text { Measuring } \\
\text { wavelengths } \\
\text { (nm) }\end{array}$ \\
\hline Astra 8 (1) & 0 & 0 & 520 \\
Astra 8 (2) & 0 & 0 & 520 \\
AU 5000 (2) & 0 & $-12 \%$ & $520 / 600$ \\
AU 510 (1) & 0 & 0 & $520 / 570$ \\
Chem 1 (1) & $-25 \%$ & $-12 \%$ & $500 / 600$ \\
Chem 1 (2) & $-15 \%$ & $-25 \%$ & $500 / 600$ \\
CX 7 (1) & 0 & 0 & $520 / 560$ \\
CX 7 (2) & $-20 \%$ & 1 & $520 / 560$ \\
Dax 72 & $-25 \%$ & $-20 \%$ & $500 / 604$ \\
Dimension (1) & $-16 \%$ & $/$ & $510 / 700$ \\
Dimension (2) & $-16 \%$ & 0 & $510 / 700$ \\
Hitachi 717 (2) & 0 & 0 & 505 \\
Hitachi 717 (3) & $-15 \%$ & $-11 \%$ & $505 / 570$ \\
Hitachi 737 & 0 & $-14 \%$ & $505 / 570$ \\
Hitachi 747 & 0 & $/$ & 505 \\
Monarch (1) & 0 & 0 & 520 \\
Monarch (2) & 0 & 0 & 520 \\
Paramax (1) & $+46 \%$ & 0 & $525 / 630$ \\
Paramax (2) & 0 & 0 & $525 / 630$ \\
Wako 30 R & $+250 \% ?$ & $/$ & $500 / 572$ \\
\hline
\end{tabular}

Italic numbers = significant interference (according to the norms) at the highest level of interference

Haemoglobin absorbs strongly at $415 \mathrm{~nm}$ ("Soret peak"), and less so between 530 and $600 \mathrm{~nm}$, having 2 peaks at 540 and $570 \mathrm{~nm}$ (fig. 5) (2, 3). Therefore it may greatly interfere with measurements at these wavelengths (diazo-bilirubin, biuret total proteins). However, the structure of haemoglobin varies with the medium, precipitating in acid media, converting to haematin in alkaline media, becoming reduced, forming methaemoglobin or even carboxy or sulphohaemoglobin. These all have different spectra which will modify the extent of interference.

Bilirubin has a high absorbance between 400 and 520 $\mathrm{nm}$ (see fig. 5) and may interfere with the measurement of creatinine using the Jaffé method (tab. 12). Apparently, using a secondary wavelength does not correct this effect.

\subsubsection{Chemical interference}

The presence of foreign molecules in the solution may cause interference at different stages of the reaction, consuming some of the products.

The effect of haemoglobin on bilirubin measurement has been well-defined and is typical of this type of interference (tab. 13, in $68 \%$ of cases). In this case the spectral interference must also be taken into account as azobilirubin is measured at $540 \mathrm{~nm}$ corresponding to one of the wavelengths at which oxyhaemoglobin absorbs. However, if the $\mathrm{pH}$ changes duting the reaction, the 
Tab. 13 The influence of haemoglobin on bilirubin measurement.

\begin{tabular}{llc}
\hline Method group & Instrument & Haemolysis \\
\hline Jendrassik & AU 5000 (2) & $-60 \%$ \\
(benzoate caffeine) & CX 7 (1) & $+47 \%$ \\
neutral pH & CX 7 (2) & $+33 \%$ \\
& Dimension (1) & 0 \\
as above & Dimension (2) & 0 \\
alkaline pH & Hitachi 717 (2) & $-49 \%$ \\
& Hitachi 717 (3) & $-50 \%$ \\
Jendrassik & Hitachi 737 & $-19 \%$ \\
(DMSO) neutral pH & Open 30 (1) & $-19 \%$ \\
Diphenyl diazonium & Open 30 (2) & $-30 \%$ \\
& AU 510 (1) & $-43 \%$ \\
& AU 510 (2) & $+55 \%$ \\
& AU 5010 (1) & 0 \\
& Hitachi 717 (1) & 0 \\
& Hitachi 747 & $-78 \%$ \\
other diazo reagents & Chem 1 (1) & 0 \\
& Chem 1 (2) & 0 \\
& Dax 72 & $-36 \%$ \\
& Monarch (1) & 0 \\
& Monarch (2) & 0 \\
& Paramax (1) & $+75 \%$ \\
& Paramax (2) & $+20 \%$ \\
& Wako 30 R & $+543 \%$ \\
& Ektachem (1) & $+37 \%$ \\
& Ektachem (2) & $+34 \%$ \\
\hline
\end{tabular}

Italic numbers = significant interference (according to the norms) at the highest level of interference

haemoglobin may be transformed to haematin or methaemoglobin. At the same time, the bilirubin being measured is destroyed by haemoglobin peroxidase. On top of this, the reaction kinetics of the blank, if used, may differ from the sample so that the interference will be positive without a blank and negative with a blank.

Bilirubin may also interfere as a reducing substance: as it is easily oxidised to biliverdin and bilipurpurin, it will react with all oxidants present. Many enzymatic tests used for measuring substrates use oxidases producing hydrogen peroxide. In the presence of peroxidase, different chromogens can be oxidised. Bilirubin may reduce the concentration of the final product proportionally to its own concentration by consuming the hydrogen peroxide. Here we may find an augmented effect due to the spectral changes in the medium caused by the oxidation of bilirubin (fig. 6). This explains why the results are systematically too low with the oxidase/peroxidase methods (tab. 14) for glucose, cholesterol, triacylglycerols and uric acid. This is also true for the enzymatic creatinine method on the Hitachi 717 (1) (tab. 6).

Lastly, bilirubin oxidises spontaneously in an alkaline medium, as in the Jaffé method for creatinine (tab. 12). This is probably the main reasons for the interferences found, rather than any spectral effects.

\subsection{How do the instruments deal with this problem?}

Basically, it is impossible to eliminate some kind of interferences - e.g. those caused by cell lysis. It is nevertheless possible to influence spectral and chemical interferences.

Tab. 14 Oxidase/peroxidase methods - The influence of bilirubin.

\begin{tabular}{|c|c|c|c|c|c|c|c|c|}
\hline \multirow[t]{2}{*}{ Instrument } & \multicolumn{2}{|l|}{ Glucose } & \multicolumn{2}{|c|}{ Cholesterol } & \multicolumn{2}{|c|}{ Triacylglycerols } & \multicolumn{2}{|l|}{ Uric acid } \\
\hline & bilirubin & $\begin{array}{l}\text { ditauro- } \\
\text { bilirubin }\end{array}$ & bilirubin & $\begin{array}{l}\text { ditauro- } \\
\text { bilirubin }\end{array}$ & bilirubin & $\begin{array}{l}\text { ditauro- } \\
\text { bilirubin }\end{array}$ & bilirubin & $\begin{array}{l}\text { ditauro- } \\
\text { bilirubin }\end{array}$ \\
\hline AU 5000 (2) & $-43 \%$ & $-20 \%$ & I & I & I & 1 & I & I \\
\hline AU 5010 (1) & 1 & 1 & $-42 \%$ & $-15 \%$ & 0 & $-25 \%$ & $-11 \%$ & $-19 \%$ \\
\hline AU 510 (1) & 1 & i & $-31 \%$ & $-20 \%$ & 0 & $-24 \%$ & 0 & $-43 \%$ \\
\hline AU 510 (2) & $-21 \%$ & $-14 \%$ & $-33 \%$ & $-19 \%$ & $+19 \%$ & $-45 \%$ & 1 & 1 \\
\hline Chem 1 (1) & 1 & 1 & 0 & $-13 \%$ & 1 & 1 & I & I \\
\hline Chem 1 (2) & I & I & 0 & $-19 \%$ & 1 & 1 & 1 & I \\
\hline $\mathrm{CX} 7(2)$ & 1 & 1 & $-34 \%$ & 1 & $-78 \%$ & 1 & 1 & 1 \\
\hline $\operatorname{Dax} 72$ & $-19 \%$ & $-12 \%$ & $?$ & $-20 \%$ & 0 & 0 & $-34 \%$ & $-32 \%$ \\
\hline Hitachi 717 (1) & $=18 \%$ & 0 & i & 1 & 1 & l & $-41 \%$ & $-23 \%$ \\
\hline Hitachi 717 (2) & $-27 \%$ & 0 & $-20 \%$ & $-11 \%$ & 0 & 0 & $-29 \%$ & $-23 \%$ \\
\hline Hitachi 737 & 0 & 0 & 0 & 0 & 0 & 0 & $-20 \%$ & $-17 \%$ \\
\hline Hitachi 747 & $-15 \%$ & 1 & $-20 \%$ & I & $-17 \%$ & 1 & $-30 \%$ & 1 \\
\hline Monarch (1) & $-26 \%$ & $-9 \%$ & $-17 \%$ & 0 & 0 & 0 & 0 & $-20 \%$ \\
\hline Monarch (2) & $-13 \%$ & 0 & $-12 \%$ & $-15 \%$ & 0 & 0 & 0 & $-11 \%$ \\
\hline Open 30 (1) & 1 & 1 & $-17 \%$ & 0 & 1 & I & 1 & 1 \\
\hline Open 30 (2) & I & I & $-18 \%$ & 0 & $-59 \%$ & $-33 \%$ & I & I \\
\hline Paramax (1) & I & I & $-15 \%$ & $-11 \%$ & 1 & I & $-17 \%$ & 0 \\
\hline Paramax (2) & 1 & I & $-20 \%$ & $-17 \%$ & 1 & I & $-12 \%$ & 0 \\
\hline Wako $30 \mathrm{R}$ & $-16 \%$ & 1 & $-29 \%$ & 1 & $-17 \%$ & 1 & 0 & 1 \\
\hline
\end{tabular}

Values in italics = significant interference (according to the norms) at the highest level of interference 


\subsubsection{Physical removal of impurities}

This study confirms the previous one published by Glick in $1986(5,6)$ which showed that instruments using specimen pretreatment (strips with a layer for separation, dialysis) were best at eliminating both spectral and chemical interferences. In the same way, the SFBC method for iron chemically eliminates interference using trichloroacetic acid prior to carrying out the assay. The Kodak multilayer slides have a similar effect though, to a lesser extent, through the use of hydrophilic polymers on which the sample is deposited and which allow the passage of a set volume of aqueous liquid via capillaries. This blocks macromolecules and other substances which could interfere with measurement.

\subsubsection{Operational conditions - Blank measurement}

"Visible" interferences, particularly turbidity (4), may be minimised or even corrected by adjusting the reaction medium using e.g. a sample blank.

a) blank measurement: This involves measuring the sample absorbance, once suitably diluted, prior to adding the reagent. The absorbance measured (A1) is subtracted from the final absorbance (A2). There are several ways to realize this blank. The first method uses two different reagents (blank and reagent mixture) and two cuvettes. The second method is performed by sequentially adding the reagents which, however, is not always possible: some automated systems work only with a single reagent, or only have one position to dispense the reagents. Furthermore, these methods need two consecutive measurements on the same sample. Finally, a single reagent may be used with an early reading which is ranked as a blank, or with multiple readings to estimate the blank value. This, however, requires successive measurements on the same sample: if certain automated systems having several photometers have a limited number of measurements at fixed intervals, others systems only have one photometer. In that case, we will distinguish between the few automated systems which can only measure at the end point, and the many automated systems which, fortunately, can make several measurements. Here, the photometer may well be fixed, but the cuvettes will be transported in front of the photometer for readings at set intervals. If it is mobile, it will be able to read absorbances on all the cuvettes at the required times. These settings mean that many readings can be made for each sample and thus a blank value can be easily obtained.

This shows how important the concept of an instrument is, as well as the available algorithms, at different levels (treatment of the reaction medium, treatment of the readings, treatment of other data, e.g. the number of reagents per test, the number of readings per cuvette
Tab. 15 The interest of 2-cuvette blanking.

\begin{tabular}{|c|c|c|c|}
\hline & Instrument & Turbidity & Sample blank \\
\hline \multirow[t]{2}{*}{ Iron } & AU $510(1)$ & 0 & $\begin{array}{l}\text { yes, } 2 \text { cu- } \\
\text { vettes }\end{array}$ \\
\hline & AU $510(2)$ & $-100 \% ?$ & yes, sequential \\
\hline \multirow[t]{3}{*}{ Phosphorus } & AU $510(1)$ & 0 & $\begin{array}{l}\text { yes, } 2 \text { cu- } \\
\text { vettes }\end{array}$ \\
\hline & AU $510(2)$ & $+127 \%$ & no \\
\hline & Instrument & Haemolysis & Sample blank \\
\hline \multirow[t]{2}{*}{ Bilirubin } & Open 30 (1) & $-19 \%$ & $\begin{array}{l}\text { yes, } 2 \text { cu- } \\
\text { vettes }\end{array}$ \\
\hline & Open 30 (2) & $-30 \%$ & $\begin{array}{l}\text { yes, } 2 \mathrm{cu} \text { - } \\
\text { vettes }\end{array}$ \\
\hline
\end{tabular}

Values in italics = significant interference (according to the norms) at the highest level of interference

etc.). They both affect the quality of the results and the prevention or lack of prevention of interferences.

b) blank preparation: this also makes a difference (tab. 15). Better results are often obtained if 2 cuvettes with a blank are used rather than sequentially adding the rea gents. When the blank develops slowly, automated systems are often not able to wait for its absorbance to stabilise before adding the reagent. Under these conditions, two cuvettes may be used, one containing all the reagents and the other containing all of them except one necessary for the reaction to take place. The blank is the one in which, after the reaction time, no colour is visible. The interference will be the same in both cuvettes.

In the study, several examples show that the use of 2 cuvettes produces excellent results. For example, on the 2AU 510, one used sequential blanking, the other $2 \mathrm{cu}-$ vettes. The results (fig. 8) show the advantage of 2 cuvettes. This is not the final solution for every test as

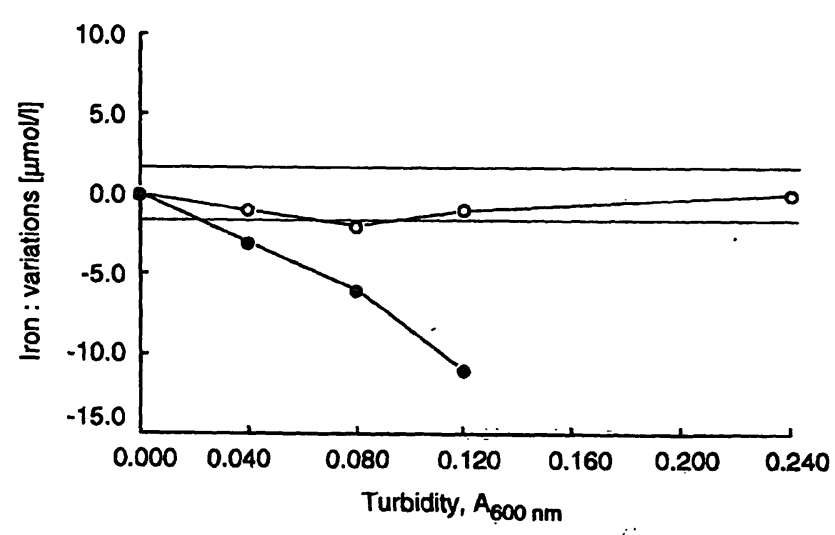

Fig. 8 The interest of 2-cuvette blanking - e.g. interference of turbidity on iron measurements on $2 \mathrm{AU} 510$ analysers using the same method and the same reagents; the first one AU 510 (1) works with a two cuvette blank, the second one AU 510 (2) with a sequential addition of reagents.

-O- AU 510 (1); - - - AU 510 (2) : 
shown in the results for bilirubin in the presence of haemolysis using 2 cuvettes: in this case, the chemical interference is difficult to remove (e. g. bilirubin on the Open 30 and the AU 510). The use of 2 cuvettes suffers one drawback reducing the throughput of tests by half, although generally improving the results overall.

\subsubsection{Measuring conditions}

Clinical chemistry analysers try, on the whole, to deal with spectral interference by acting on the readings made:

a) choice of read wavelength: the number of wavelengths available on automated systems is usually limited. They mostly use interference filters: some use light receptive arrays, but the number of diode receptors used is relative small (generally from 10 to 16). Thus, the wavelength used is not always the best. For example, the interference of bilirubin and haemolysis on uric acid measurement using the oxidase/peroxidase methods (tab. 16) varies with the wavelength.

b) Multiwavelength analysis appears attractive: since the interference may vary with time, corrections can be carried out at the end of the reaction by reading at different wavelengths and applying algorithms for correction. The easiest - and almost the only - method used in our experience in 1992, is bichromatic measurement. This involves using a secondary (side) wavelength to measure the interfering substance. The substance to be measured does not absorb at this wavelength. This measurement is then subtracted from that of the analyte required at its wavelength. This assumes that the absorbance of the interfering substance is the same at both wavelengths, which is rarely the case. Obviously, the bichromatic principle will not help unless the interfering substance does not absorb at the secondary wavelength. For

Tab. 16 Uric acid, uricase Trinder methods: the influence of haemolysis and bilirubin at different wavelengths.

\begin{tabular}{lcll}
\hline Instrument & Häemolysis & $\begin{array}{l}\text { Total } \\
\text { bilirubin }\end{array}$ & $\begin{array}{l}\text { Wavelength } \\
(\mathrm{nm})\end{array}$ \\
\hline Hitachi $717(1)$ & $+15 \%$ & $-41 \%$ & \\
Hitachi $717(2)$ & 0 & $-29 \%$ & 505 \\
Hitachi 747 & $+18 \%$ & $-30 \%$ & \\
Dax 72 & $+31 \%$ & $-34 \%$ & \\
Paramax (1) & $+16 \%$ & $-17 \%$ & 525 \\
Paramax (2) & $+29 \%$ & $-12 \%$ & \\
Monarch (1) & $+58 \%$ & 0 & \\
Monarch (2) & $+27 \%$ & 0 & 550 \\
Wako 30 R & $+215 \%$ & 0 & \\
AU 510 (1) & $+47 \%$ & 0 & \\
AU 5010 (1) & $+42 \%$ & $-11 \%$ & 570 \\
Hitachi 737 & $+36 \%$ & $-20 \%$ & \\
\hline
\end{tabular}

this reason, the corrections will either be partial or overestimated.

\subsection{What can be obtained from the results?}

By taking some relatively complex examples, we shall see that mastering "visible" interferences is very difficult if not impossible.

\subsubsection{The uric acid case}

Table 17 shows the results obtained: the instruments are listed by method, for the most part "uricase/catalase/dehydrogenase" and "uricase/peroxidase" with rarely "uricase $293 \mathrm{~nm}$ " and "uricase by reflectance photometry".

Clearly, the "uricase/catalase/dehydrogenase" methods come out better than the "uricase peroxidase" methods which are often subject to interference (bilirubin and haemolysis in particular). Wherever possible on open systems, both manufacturers and end users should use the "uricase/catalase/dehydrogenase" methods. The influence of turbidity on the Chem 1 is surprising: the instrument uses sequential additions and there is probably a clarification of the reaction medium after the first reading.

For the "uricase/peroxidase" methods which very often use the Trinder's chromogen (4-aminophenazone and phenol or phenol derivatives), the choice of the secondary wavelength does not always appear to be the most appropriate. The same can be said for the other tests using these methods (glucose, cholesterol, triacylglycerols). Here we find virtually any wavelength (tab. 18). It seems that the best wavelength would be $560 \mathrm{~nm}$, where haemoglobin and bilirubin absorbance is minimal, but the choice depends on the substrate used in the indicator reaction. It is also interesting to note that the sensitivity varies according to chromogen used - phenol bonded with halogens to varying degrees, $p$-chlorophenol, dichlorhydroxybenzene-sulphonic acid - which itself depends on the concentration of the substrate (glucose and cholesterol 5, triacylglycerols 2 , uric acid 0.5 ). This leads to paradoxical results when considering that interferences - e.g. cholesterol and glucose - are more señsitive to bilirubin.

As for haemolysis, the uric acid test, using this method, suffers greater interference than other tests using the methods (cholesterol, glucose, triacylglycerols), which are diluted $1: 100$, whereas to improve sensitivity, uric acid is only diluted $1: 50$.

Finally, a sample blank only improves results where lipids are in excess. 
Tab. 17 Uric acid measurement.

\begin{tabular}{|c|c|c|c|c|c|c|c|c|}
\hline \multirow[t]{2}{*}{ Method group } & \multirow[t]{2}{*}{ Instrument } & \multirow[t]{2}{*}{ Bilirubin } & \multirow{2}{*}{$\begin{array}{l}\text { Ditauro- } \\
\text { bilirubin }\end{array}$} & \multirow[t]{2}{*}{ Haemolysis } & \multirow[t]{2}{*}{ Turbidity } & \multirow{2}{*}{$\begin{array}{l}\text { Sample } \\
\text { blank }\end{array}$} & \multicolumn{2}{|c|}{ Wavelength } \\
\hline & & & & & & & main & side \\
\hline $\begin{array}{l}\text { Uricase/ } \\
\text { catalase/ } \\
\text { dehydrogenase }\end{array}$ & $\begin{array}{l}\text { AU } 5000(2) \\
\text { AU } 510(2) \\
\text { Chem } 1(1) \\
\text { Chem } 1(2) \\
\text { CX } 7(1) \\
\text { CX } 7(2) \\
\text { Open } 30(1) \\
\text { Open } 30(2)\end{array}$ & $\begin{array}{c}-22 \% \\
0 \\
0 \\
0 \\
0 \\
0 \\
0 \\
0\end{array}$ & $\begin{array}{l}0 \\
0 \\
0 \\
0 \\
0 \\
1 \\
0 \\
0\end{array}$ & $\begin{array}{c}0 \\
0 \\
+13 \% \\
0 \\
-11 \% \\
0 \\
0 \\
-11 \%\end{array}$ & $\begin{array}{c}+12 \% \\
+22 \% \\
-61 \% ? \\
-50 \% ? \\
-15 \% ? \\
-10 \% \\
0 \\
0\end{array}$ & $\begin{array}{l}\text { yes } \\
\text { yés' } \\
\text { yes } \\
\text { yes } \\
\text { yes } \\
\text { yes } \\
\text { yes } \\
\text { yes }\end{array}$ & $\begin{array}{l}340 \\
340 \\
340 \\
340 \\
340 \\
340 \\
340 \\
340\end{array}$ & $\begin{array}{c}380 \\
380 \\
I \\
I \\
380 \\
380 \\
I \\
I\end{array}$ \\
\hline $\begin{array}{l}\text { Uricase/ } \\
\text { peroxidase }\end{array}$ & $\begin{array}{l}\text { AU } 5010(1) \\
\text { AU } 510(1) \\
\text { Dax } 72 \\
\text { Hitachi } 717(1) \\
\text { Hitachi } 717(2) \\
\text { Hitachi } 737 \\
\text { Hitachi } 747 \\
\text { Monarch (1) } \\
\text { Monarch (2) } \\
\text { Paramax (1) } \\
\text { Paramax (2) } \\
\text { Wako } 30 \mathrm{R}\end{array}$ & $\begin{array}{c}-11 \% \\
0 \\
-34 \% \\
-41 \% \\
-29 \% \\
-20 \% \\
-30 \% \\
0 \\
0 \\
-17 \% \\
-12 \% \\
0\end{array}$ & $\begin{array}{c}-19 \% \\
-43 \% \\
-32 \% \\
-23 \% \\
-23 \% \\
-17 \% \\
1 \\
-20 \% \\
-11 \% \\
0 \\
0 \\
1\end{array}$ & $\begin{array}{c}+42 \% \\
+47 \% \\
+31 \% \\
+15 \% \\
0 \\
+36 \% \\
+18 \% \\
+58 \% \\
+27 \% \\
+16 \% \\
+29 \% \\
+215 \%\end{array}$ & $\begin{array}{c}0 \\
0 \\
+50 \% \\
0 \\
0 \\
0 \\
0 \\
0 \\
-50 \% \\
+19 \% \\
+20 \% \\
0\end{array}$ & $\begin{array}{l}\text { yes } \\
\text { no } \\
\text { no } \\
\text { yes } \\
\text { no } \\
\text { yes } \\
\text { yes } \\
\text { no } \\
\text { no } \\
\text { no } \\
\text { no } \\
\text { no }\end{array}$ & $\begin{array}{l}570 \\
570 \\
524 \\
505 \\
505 \\
570 \\
505 \\
550 \\
550 \\
525 \\
525 \\
546\end{array}$ & $\begin{array}{c}750 \\
800 \\
604 \\
700 \\
/ \\
660 \\
/ \\
690 \\
690 \\
630 \\
630 \\
700\end{array}$ \\
\hline Uricase $293 \mathrm{~nm}$ & $\begin{array}{l}\text { Dimension (1) } \\
\text { Dimension (2) }\end{array}$ & $\begin{array}{l}0 \\
0\end{array}$ & $\begin{array}{l}1 \\
0\end{array}$ & $\begin{array}{l}0 \\
0\end{array}$ & $\begin{array}{l}1 \\
0\end{array}$ & $\begin{array}{l}\text { yes } \\
\text { yes }\end{array}$ & $\begin{array}{l}293 \\
293\end{array}$ & $\begin{array}{l}700 \\
700\end{array}$ \\
\hline $\begin{array}{l}\text { Uricase/ } \\
\text { reflectometry }\end{array}$ & $\begin{array}{l}\text { Ektachem (1) } \\
\text { Ektachem (2) }\end{array}$ & $\begin{array}{l}0 \\
0\end{array}$ & $\begin{array}{l}0 \\
0\end{array}$ & $\begin{array}{l}0 \\
0\end{array}$ & $\begin{array}{l}0 \\
0\end{array}$ & l & $\begin{array}{l}1 \\
1\end{array}$ & $1=$ \\
\hline
\end{tabular}

Italic numbers $=$ significant interference (according to the norms) at the highest level of interference

Tab. 18 Oxidase/peroxidase methods - choice of main and side wavelengths.

\begin{tabular}{|c|c|c|c|c|}
\hline Instrument & $\begin{array}{l}\text { Glucose } \\
\text { wavelengths } \\
(\mathrm{nm})\end{array}$ & $\begin{array}{l}\text { Cholesterol } \\
\text { wavelengths } \\
(\mathrm{nm})\end{array}$ & $\begin{array}{l}\text { Triacylglycerols } \\
\text { wavelengths } \\
(\mathrm{nm})\end{array}$ & $\begin{array}{l}\text { Uric acid } \\
\text { wavelengths } \\
\text { (nm) }\end{array}$ \\
\hline AU 5000 (2) & $540 / 600$ & 1 & 1 & 1 \\
\hline AU 5010 (1) & 1 & $540 / 600$ & $520 / 600$ & $570 / 750$ \\
\hline AU 510 (1) & 1 & $540 / 600$ & $520 / 600$ & $570 / 800$ \\
\hline AU $510(2)$ & 520 & $540 / 600$ & $520 / 600$ & 1 \\
\hline Chem 1 (1) & 1 & 500 & 1 & 1 \\
\hline Chem 1 (2) & 1 & 500 & 1 & 1 \\
\hline CX 7 (2) & 1 & $520 / 600$ & $520 / 600$ & 1 \\
\hline Dax 72 & $500 / 548$ & $524 / 604$ & $524 / 604$ & $524 / 604$ \\
\hline Hitachi 717 (1) & $505 / 700$ & 1 & 1 & $505 / 700$ \\
\hline Hitachi $717(2)$ & 505 & 505 & 505 & 505 \\
\hline Hitachi 737 & $505 / 700$ & $505 / 700$ & $505 / 700$ & $570 / 660$ \\
\hline Hitachi 747 & 505 & 505 & 505 & 505 \\
\hline Monarch (1) & 520 & $500 / 690$ & $550 / 690$ & $550 / 690$ \\
\hline Monarch (2) & $520 / 690$ & $500 / 690$ & $550 / 690$ & $550 / 690$ \\
\hline Open 30 (1) & 1 & 510 & 1 & 1 \\
\hline Open 30 (2) & I & 510 & 510 & I \\
\hline Paramax (1) & 1 & $525 / 630$ & I & $525 / 630$ \\
\hline Paramax (2) & I & $525 / 630$ & I & $525 / 630$ \\
\hline Wako $30 \mathrm{R}$ & $500 / 660$ & $548 / 700$ & $604 / 700$ & $546 / 700$ \\
\hline
\end{tabular}

Italic numbers = significant interference (according to the norms) at the highest level of interference

\subsubsection{The bilirubin case}

In our study, this test was the most sensitive to interference (tab. 19); the assay suffered interference in $50 \%$ of cases (haemolysis: $68 \%$ - turbidity: $32 \%$ ). Bilirubin is apparently difficult to measure in a haemolysed specimen ... .Thus blanking is needed (and is effective) to prevent lipaemic interference but does not influence haemolysis: using a blank produces a negative effect (bilirubin degradation?) and withoüt one, the interference 
Tab. 19 Bilirubin measurement.

\begin{tabular}{|c|c|c|c|c|c|c|}
\hline Method group & Instrument & Haemolysis & Turbidity & $\begin{array}{l}\text { Sample } \\
\text { Blank }\end{array}$ & $\begin{array}{l}\text { No. of } \\
\text { reagents }\end{array}$ & $\begin{array}{l}\text { Wavelengths } \\
(\mathrm{nm}) \\
\text { main/side }\end{array}$ \\
\hline $\begin{array}{l}\text { Jendrassik } \\
\text { (benzoate caffeine) } \\
\text { neutral pH }\end{array}$ & $\begin{array}{l}\text { AU } 5000 \text { (2) } \\
\text { CX } 7(1) \\
\text { CX } 7 \text { (2) } \\
\text { Dimension (1) } \\
\text { Dimension (2) }\end{array}$ & $\begin{array}{c}-60 \% \\
+47 \% \\
+33 \% \\
0 \\
0\end{array}$ & $\begin{array}{c}0 \\
+31 \% \\
+19 \% \\
0 \\
0\end{array}$ & $\begin{array}{l}\text { yes? } \\
\text { no } \\
\text { no } \\
\text { yes? } \\
\text { yes? }\end{array}$ & $\begin{array}{l}2 \\
2^{*} \\
2^{*} \\
2 \\
2\end{array}$ & $\begin{array}{l}540 / 600 \\
560 / 600 \\
560 / 600 \\
540 / 700 \\
540 / 700\end{array}$ \\
\hline as above alkaline $\mathrm{pH}$ & $\begin{array}{l}\text { Hitachi } 717(2) \\
\text { Hitachi } 717(3) \\
\text { Hitachi } 737\end{array}$ & $\begin{array}{l}-49 \% \\
-50 \% \\
-19 \%\end{array}$ & $\begin{array}{l}0 \\
0 \\
0\end{array}$ & $\begin{array}{l}\text { yes } \\
\text { yes } \\
\text { yes }\end{array}$ & $\begin{array}{l}2 \\
2 \\
2\end{array}$ & $\begin{array}{l}546 \\
546 / 660 \\
546 / 660\end{array}$ \\
\hline $\begin{array}{l}\text { Jendrassik } \\
\text { (DMSO) neutral pH }\end{array}$ & $\begin{array}{l}\text { Open } 30(1) \\
\text { Open } 30(2)\end{array}$ & $\begin{array}{l}-19 \% \\
-30 \%\end{array}$ & $\begin{array}{l}0 \\
0\end{array}$ & $\begin{array}{l}\text { yes, } 2 \text { cuvettes } \\
\text { yes, } 2 \text { cuvettes }\end{array}$ & $\begin{array}{l}1 \\
1\end{array}$ & $\begin{array}{l}550 \\
550\end{array}$ \\
\hline Diphenyl diazonium & $\begin{array}{l}\text { AU } 510(1) \\
\text { AU } 510(2) \\
\text { AU } 5010(1) \\
\text { Hitachi } 717(1) \\
\text { Hitachi } 747\end{array}$ & $\begin{array}{c}-43 \% \\
+55 \% \\
0 \\
0 \\
-78 \%\end{array}$ & $\begin{array}{c}0 \\
0 \\
0 \\
-30 \% \\
0\end{array}$ & $\begin{array}{l}\text { yes, } 2 \text { cuvettes } \\
\text { no } \\
\text { yes } \\
\text { yes } \\
\text { yes }\end{array}$ & $\begin{array}{l}1 \\
1 \\
2 \\
2 \\
2\end{array}$ & $\begin{array}{l}540 / 600 \\
540 / 600 \\
540 / 600 \\
570 / 660 \\
546 / 660\end{array}$ \\
\hline other diazo reagents & $\begin{array}{l}\text { Chem } 1(1) \\
\text { Chem } 1(2) \\
\text { Dax } 72 \\
\text { Monarch (1) } \\
\text { Monarch (2) } \\
\text { Paramax (1) } \\
\text { Paramax (2) } \\
\text { Wako } 30 \mathrm{R}\end{array}$ & $\begin{array}{c}0 \\
0 \\
-36 \% \\
0 \\
0 \\
+75 \% \\
+20 \% \\
+543 \%\end{array}$ & $\begin{array}{c}0 \\
0 \\
+25 \% \\
+75 \% \\
+78 \% \\
+35 \% \\
+46 \% \\
+245 \%\end{array}$ & $\begin{array}{l}\text { yes } \\
\text { yes } \\
\text { yes, } 2 \text { cuvettes } \\
\text { no } \\
\text { no } \\
\text { no } \\
\text { no } \\
?\end{array}$ & $\begin{array}{l}2 \\
2 \\
1 \\
2 \\
2 \\
1 \\
1 \\
2\end{array}$ & $\begin{array}{l}550 \\
550 \\
548 / 628 \\
550 / 620 \\
550 / 620 \\
550 / 630 \\
550 / 630 \\
604 / 700\end{array}$ \\
\hline Reflectometry & $\begin{array}{l}\text { Ektachem (1) } \\
\text { Ektachem (2) }\end{array}$ & $\begin{array}{l}+37 \% \\
+34 \%\end{array}$ & $\begin{array}{l}0 \\
0\end{array}$ & 1 & $\begin{array}{l}1 \\
1\end{array}$ & 1 \\
\hline
\end{tabular}

DMSO = Dimethylsulphoxide

* the two reagents are added simultaneously

Values in italics = significant interference (according to the norms) at the highest level of interference

is positive; this is well illustrated by the results obtained on the AU 510 working with single reagents: system (1) uses a blank and has a negative interference; system (2) has none and has a positive interference. The choice of primary wavelength is also important: haemoglobin has 2 peaks at 540 and $575 \mathrm{~nm}$, and 2 minimum absorbance at 509 and $559 \mathrm{~nm}$ (fig. 5). This interference is also seen on the Ektachem.

\subsubsection{The case of iron measurement}

Iron, in the present study, is very sensitive to interference (tab. 20): results are affected in $23.4 \%$ of cases overall (haemolysis: $64.6 \%$ - turbidity: $23.5 \%$ ).

The interference caused by haemolysis is quite interesting since one micromole of haemoglobin (monomer) contains one micromole of iron. Thus, the final point of addition at $240 \mu \mathrm{mol} / 1$ of haemoglobin represents a large increase in iron in the specimen which would appear to make this test of no interest. However, for reasons we are unable to understand, there is no interference observed with certain reagents. In fact, this depends especially on the $\mathrm{pH}$ of the reaction medium and the de- tergents used in the reagents: if the iron is not released but interference still exists, this is probably optical, and should not be seen if a sample blank is used; if the iron is released, it would be "normal" to see an interference of $1200 \%$.

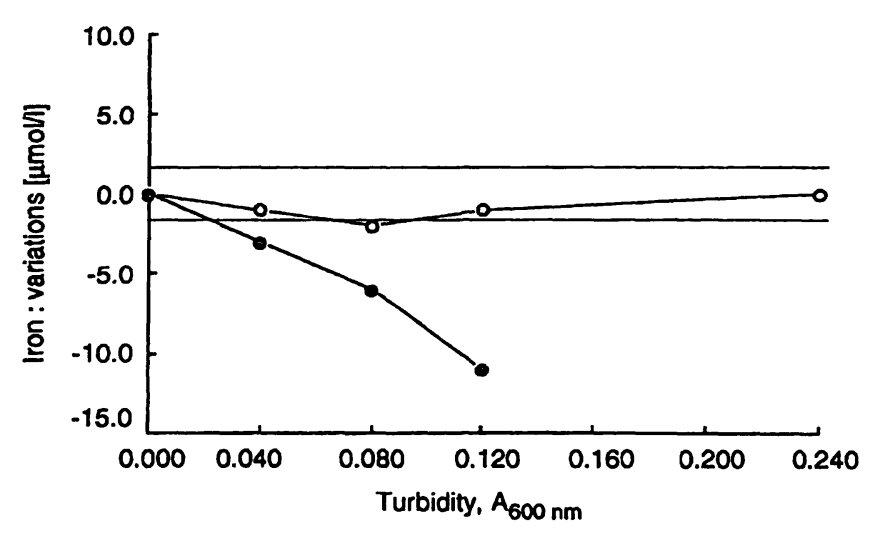

Fig. 8 The interest of 2-cuvette blanking - e.g. interference of turbidity on iron measurements on $2 \mathrm{AU} 510$ analysers using the same method and the same reagents; the first one AU 510 (1) works with a two cuvette blank, the second one AU 510 (2) with a sequential addition of reagents.

-O- AU 510 (1); - - - AU 510 (2) 
Tab. 20 Iron measurement.

\begin{tabular}{|c|c|c|c|c|c|c|c|}
\hline $\begin{array}{l}\text { Method } \\
\text { group }\end{array}$ & Instrument & Bilirubin & $\begin{array}{l}\text { Ditauro- } \\
\text { bilirubin }\end{array}$ & Haemolysis & Turbidity & $\begin{array}{l}\text { Sample } \\
\text { Blank }\end{array}$ & $\begin{array}{l}\text { Wavelengths } \\
\text { (nm) } \\
\text { main/side }\end{array}$ \\
\hline Ferrozine & $\begin{array}{l}\text { AU } 510(1) \\
\text { AU } 510(2) \\
\text { CX } 7(2) \\
\text { Hitachi } 717(3) \\
\text { Hitachi } 747 \\
\text { Open } 30(2) \\
\text { Paramax (1) } \\
\text { Paramax (2) } \\
\text { Wako } 30 \mathrm{R}\end{array}$ & $\begin{array}{c}0 \\
0 \\
0 \\
0 \\
0 \\
0 \\
+10 \% \\
+17 \% \\
0\end{array}$ & $\begin{array}{c}0 \\
0 \\
1 \\
0 \\
1 \\
0 \\
0 \\
+14 \% \\
1\end{array}$ & $\begin{array}{c}+81 \% \\
+64 \% \\
-50 \% \\
+94 \% \\
+13 \% \\
0 \\
+62 \% \\
+49 \% \\
+295 \%\end{array}$ & $\begin{array}{c}0 \\
-100 \% ? \\
-14 \% \\
0 \\
>-100 \% \\
+17 \% \\
+9 \% \\
0 \\
+13 \%\end{array}$ & $\begin{array}{l}\text { yes, } 2 \text { cuvettes } \\
\text { yes, sequential } \\
\text { yes } \\
\text { yes } \\
\text { yes } \\
\text { yes } \\
\text { yes } \\
\text { yes } \\
\text { yes }\end{array}$ & $\begin{array}{l}570 / 660 \\
570 / 660 \\
560 / 700 \\
570 / 700 \\
570 \\
550 \\
550 / 630 \\
550 / 630 \\
572 / 700\end{array}$ \\
\hline Ferene & $\begin{array}{l}\text { Chem } 1(1) \\
\text { Chem } 1 \text { (2) } \\
\text { Dimension (1) } \\
\text { Dimension (2) } \\
\text { Hitachi } 717 \text { (2) } \\
\text { Hitachi } 737 \\
\text { Monarch (1) }\end{array}$ & $\begin{array}{c}0 \\
+12 \% \\
0 \\
0 \\
+14 \% \\
0 \\
0\end{array}$ & $\begin{array}{l}0 \\
0 \\
1 \\
0 \\
0 \\
0 \\
0\end{array}$ & $\begin{array}{c}0 \\
0 \\
+187 \% \\
+150 \% \\
+140 \% \\
+17 \% \\
+131 \%\end{array}$ & $\begin{array}{c}0 \\
+15 \% \\
0 \\
0 \\
+74 \% \\
+13 \% \\
+241 \%\end{array}$ & $\begin{array}{l}\text { yes } \\
\text { yes } \\
\text { yes } \\
\text { yes } \\
\text { no } \\
\text { yes } \\
\text { no }\end{array}$ & $\begin{array}{l}600 \\
600 \\
600 / 700 \\
600 / 700 \\
600 \\
580 / 600\end{array}$ \\
\hline
\end{tabular}

Italic numbers $=$ significant interference (according to the norms) at the highest level of interference

Tab. 21 Phosphorus measurement using phosphomolybdate methods, reading at $340 \mathrm{~nm}$ : what using a sample blank adds.

\begin{tabular}{|c|c|c|c|c|c|c|}
\hline Instrument & Bilirubin & $\begin{array}{l}\text { Ditauro- } \\
\text { bilirubin }\end{array}$ & Haemolysis & Turbidity & $\begin{array}{l}\text { 2-Reagent } \\
\text { system }\end{array}$ & $\begin{array}{l}\text { Side } \\
\text { wavelength } \\
\text { (nm) }\end{array}$ \\
\hline AU $510(2)$ & $+14 \%$ & $+41 \%$ & $+58 \%$ & $+127 \%$ & no & no \\
\hline $\operatorname{CX} 7(1)$ & 0 & $+17 \%$ & $+29 \%$ & $+48 \%$ & no & 600 \\
\hline $\operatorname{CX} 7(2)$ & 0 & 1 & $+40 \%$ & $+74 \%$ & no & 520 \\
\hline Hitachi 717 (1) & $-57 \%$ & 0 & $? ?$ & $+53 \%$ & no & 405 \\
\hline Monarch (1) & 0 & $+20 \%$ & $+24 \%$ & $+61 \%$ & no & 520 \\
\hline Open 30 (1) & $+12 \%$ & $+26 \%$ & $+37 \%$ & $+112 \%$ & no & no \\
\hline Open $30(2)$ & $+17 \%$ & $+29 \%$ & $+37 \%$ & $+78 \%$ & no & no \\
\hline Paramax (1) & 0 & 0 & $-17 \%$ & 0 & no & 405 \\
\hline Paramax (2) & 0 & 0 & $-20 \%$ & 0 & no & 405 \\
\hline AU $510(1)$ & 0 & $+15 \%$ & $+16 \%$ & 0 & no, 2 cuvettes & 380 \\
\hline AU 5000 (2) & 0 & 0 & $+21 \%$ & 0 & yes & 380 \\
\hline AU 5010 (1) & 0 & 0 & $-17 \%$ & 0 & yes & 380 \\
\hline Chem 1 (1) & 0 & $+12 \%$ & 0 & 0 & yes & no \\
\hline Chem 1 (2) & 0 & 0 & 0 & 0 & yes & no \\
\hline Dax 72 & 0 & $+28 \%$ & $+17 \%$ & 0 & yes & 548 \\
\hline Dimension (1) & $+42 \%$ & 1 & $-77 \%$ & 0 & yes (3) & 383 \\
\hline Dimension (2) & $+44 \%$ & 0 & $-78 \%$ & 0 & yes (3) & 383 \\
\hline Hitachi 717 (2) & 0 & 0 & 0 & 0 & yes & no \\
\hline Hitachi 737 & 0 & 0 & 0 & 0 & yes & 660 \\
\hline Hitachi 747 & 0 & I & 0 & 0 & yes & no \\
\hline Waki $30 \mathrm{R}$ & 0 & 1 & 0 & 0 & yes & 660 \\
\hline
\end{tabular}

Italic numbers $=$ significant interference (according to the norms) at the highest level of interference

Looking at the turbidity effect, the results on the AU 510 show how the different types of blanking can affect results (fig. 8): system (1) uses a true blank with $2 \mathrm{cu}-$ vettes and the same and read times; the interference due to turbidity is kept under control. System (2) blanks sequentially: a first reading is taken after a set time and reagent (2) is added, the reaction incubated and a second reading is made; the results are too low as the reaction medium clarifies over time.

\subsubsection{The case of phosphorus}

This test was found to be the second most sensitive in our study (tab. 21 ): results are affected in $34.1 \%$ of cases (haemolysis: $56.5 \%$ - total bilirubin: $13 \%$ - ditaurobilirubin: $36.8 \%$ - turbidity: $30.4 \%$ ). On most systems, the same method was used: measurement of the phosphomolybdate formed in an acid medium at $340 \mathrm{~nm}$. However, this disguises many variations which are seen 
in the operating conditions: results greatly vary when a single reagent is used; on the Hitachi 717 , which uses $405 \mathrm{~nm}$ as secondary wavelength, all the interferences have an effect, whereas on the Paramax, which uses the same secondary wavelength, there is hardly no effect! The reagent composition (concentrations, surfactants and additives) certainly has something to do with this.

We were surprised to find that in 10 out of the 19 cases $(52.6 \%)$ where bilirubin and ditauro-bilirubin were tested, ditauro-bilirubin interfered more than bilirubin (positive interference). Since the reaction takes place under extremely acidic conditions $(\mathrm{pH}<1)$, not only does the accuracy suffer (hydrolysis of organic phosphoric esters), but, at this $\mathrm{pH}$, the absorption spectra of the 2 bilirubin is altered as well (fig. 7).

On the whole, it seems better to work under the following conditions: use a 2-reagent system with a sample blank either using 2 cuvettes or with sequential addition; avoid using a secondary wavelength, or one as neutral as possible $(>600 \mathrm{~nm})$.

\section{Conclusions}

This study shows that results obtained from automated systems may not always be accurate in the presence of substances like haemoglobin or bilirubin or even when the specimen is cloudy in sufficiently high concentrations in the sample. We found that results were affected in $22.5 \%$ of cases under these conditions. The risk of interference is increased by the use of primary tubes often covered by several labels preventing visual inspections of the serum or plasma.

These results confirm those of Glick $(5,6)$ published in the United States in 1986 on the automated systems on the market at that time. It confirms the different publications and sessions at congresses, found in the literature, which have discussed interference problems. They indicate the same evolution that is seen in national and regional control schemes for quality control (External QC), whereby automation has improved precision considerably, but not accuracy as can be seen in the disper- sion of the results obtained for the same test in all the laboratories.

The instrument manufacturers do employ corrective devices for interferences (blanking, bichromatic analysis). Most of these systems suffer imperfections making these corrections illusory. Available solutions however work. A few automated systems use physical methods (diffusion through a support material) to eliminate interfering substances, which is satisfactory for both chemical and spectral effects. On the other hand, progress in spectrophotometric measurement should yield good results even in the presence of coloured parasitic substances through the use of diode arrays (which can read spectra in a very short time) and computer software to treat the data obtained. These could easily be incorporated into the instruments (some already provide such equipment but do not use all the wavelengths).

Results obtained for clinical chemistry analysers can be improved in several ways: improve the preanalytic phase, use sample blanks, get optical measurements (bi or polychromatic procedures) under control. The precision on the automated systems is good and well mastered, much more so than the accuracy. This study illustrates the problems involved in accuracy and correction of interferences, as the results are very heterogeneous. There is only one way to treat chemical interferences. Eliminate the interfering substance: e. g. bilirubin with bilirubin oxidase, vitamin $\mathrm{C}$ with ascorbic oxidase.

Manufacturers try to satisfy their customers' needs, so users of automated systems have an important role to play. As soon as laboratory directors are convinced that they need accurate results, which indeed can and should improve, manufacturers will try to improve the automated systems. The choice of an automated system for the laboratory is always a big investment and will affect the quality of results. It should be as rigorous as possible in terms of quality.

Without the collaboration of the laboratory directors to carry out the tests along with the manufacturers' acceptance that their systems be tested, this study could not have been attempted. Our thanks to all and everyone concerned. 


\section{References}

1. Vassault A, Grafmeyer D, and the members of the Commission "Validation de Techniques" of the SFBC. Protocole de validation de techniques (document B). Ann Biol Clin 1986; 44:716-8.

2. Guder WG. Haemolysis as an influence and interference factor in clinical chemistry. J Clin Chem Clin Biochem 1986; 24:125-6.

3. Sonntag O. Haemolysis as an interference factor in clinical chemistry. J Clin Chem Clin Biochem 1986; 24:127-39.

4. Brady J, O'Leary N. Interference due to lipaemia in routine photometric analysis - survey of an underrated problem. Ann Clin Biochem 1994; 31:281-8.
5. Glick MR, Ryder KW, Jackson SA. Graphical comparisons of interferences in clinical chemistry instrumentation. Clin Chem 1986; 32:470-5.

6. Glick MR, Ryder KW. Interferographs, a user's guide to interferences in clinical chemistry instruments. Vol. 1. Indianapolis: Science Enterprises Inc., 1987.

D. Grafmeyer Hôpital de la Croix-Rousse

Laboratoire de Biochimie

F-69317 Lyon Cedex 04

France 